\title{
Lignocellulosic Biomass as a Substrate for Oleaginous Microorganisms: A Review
}

\author{
Gabriela Valdés ${ }^{1,2,3,+}$, Regis Teixeira Mendonça ${ }^{2,3}$ and George Aggelis $1, * \mathbb{C}$ \\ 1 Division of Genetics, Cell Biology and Development, Department of Biology, University of Patras, \\ 26504 Patras, Greece; gvaldesrodriguez@gmail.com \\ 2 Centro de Biotecnología, Universidad de Concepción, Concepción 4030000, Chile; rteixeira@udec.cl \\ 3 Facultad de Ciencias Forestales, Universidad de Concepción, Concepción 4030000, Chile \\ * Correspondence: George.Aggelis@upatras.gr \\ † Current address: Centro Regional de Investigación e Innovación para la Sostenibilidad de la Agricultura y \\ los Territorios Rurales_CERES, Pontificia Universidad Católica de Valparaíso, Valparaíso 2340000, Chile.
}

Received: 18 September 2020; Accepted: 27 October 2020; Published: 30 October 2020

check for updates

\begin{abstract}
Microorganisms capable of accumulating lipids in high percentages, known as oleaginous microorganisms, have been widely studied as an alternative for producing oleochemicals and biofuels. Microbial lipid, so-called Single Cell Oil (SCO), production depends on several growth parameters, including the nature of the carbon substrate, which must be efficiently taken up and converted into storage lipid. On the other hand, substrates considered for large scale applications must be abundant and of low acquisition cost. Among others, lignocellulosic biomass is a promising renewable substrate containing high percentages of assimilable sugars (hexoses and pentoses). However, it is also highly recalcitrant, and therefore it requires specific pretreatments in order to release its assimilable components. The main drawback of lignocellulose pretreatment is the generation of several by-products that can inhibit the microbial metabolism. In this review, we discuss the main aspects related to the cultivation of oleaginous microorganisms using lignocellulosic biomass as substrate, hoping to contribute to the development of a sustainable process for SCO production in the near future.
\end{abstract}

Keywords: oleaginous microorganisms; microbial lipids; lignocellulose pretreatment; enzymatic hydrolysis; inhibitors

\section{Introduction}

The development of new products to meet the needs of the world's population is currently focused on processes that preserve environment healthy. Single Cell Oil (SCO) is one of the new products that has been recognized in the last decade to be an alternative to biofuels, oleochemicals and edible oils [1-9]. SCOs produced from oleaginous microorganisms have similar chemical characteristics to plant lipids. However, one of the greatest advantages of oleaginous microorganisms over vegetable crops is that they require less land and have shorter growth periods [10].

Effective SCO production requires the selection of suitable growth conditions, in which the microorganism's maximum ability to convert the carbon substrate into storage lipid can be expressed. Considering the perspective of commercial applications, special attention should be paid to the substrate acquisition cost, because this represents $40-80 \%$ of the total production cost [11]. The lignocellulosic biomass is a great option, because it is a renewable and abundant substrate, containing important amounts of assimilable sugars [12]. However, due to its structure and macromolecular composition, lignocellulose is highly recalcitrant and request special chemical, physical or biological pretreatment $[13,14]$, during which, together with assimilable sugars, several by-products 
that may inhibit microbial growth and/or lipogenesis are released [15]. Several approaches to overcome the inhibitory effects of the by-products of lignocellulose pretreatment and increase lipid productivities have been proposed. Among them, pretreatment techniques that generate less inhibitory compounds or a detoxification system able to reduce their concentration have been considered [16]. Additionally, genetic and metabolic engineering techniques [17,18], evolutionary adaptation $[19,20]$ and the use of specialized microbial consortia [21-24] offer new approaches to lignocellulose biotechnological valorization. However, the technological level achieved so far is still insufficient to support cost-effective SCO production.

The aim of this review is to discuss recent research dealing with lignocellulosic biomass pretreatment and provide a comprehensive view concerning the growth of oleaginous microorganisms and lipid production on substrates of lignocellulosic origin.

\section{Oleaginous Microorganisms}

\subsection{Important Oleaginous Species}

The microorganisms characterized as oleaginous share the common feature of being able to accumulate chemical energy in the form of lipids. The metabolism of these organisms is adapted to convert under specific growth conditions the carbon substrate into storage lipids which are stored in the cytoplasm as lipid bodies with preserved structures in prokaryotes and eukaryotes [25]. Representative oleaginous cells containing lipid bodies are shown in Figure 1. In eukaryotes, and rarely in prokaryotes, lipid bodies consist of neutral lipids, mainly triacylglycerols (TAGs) [26].

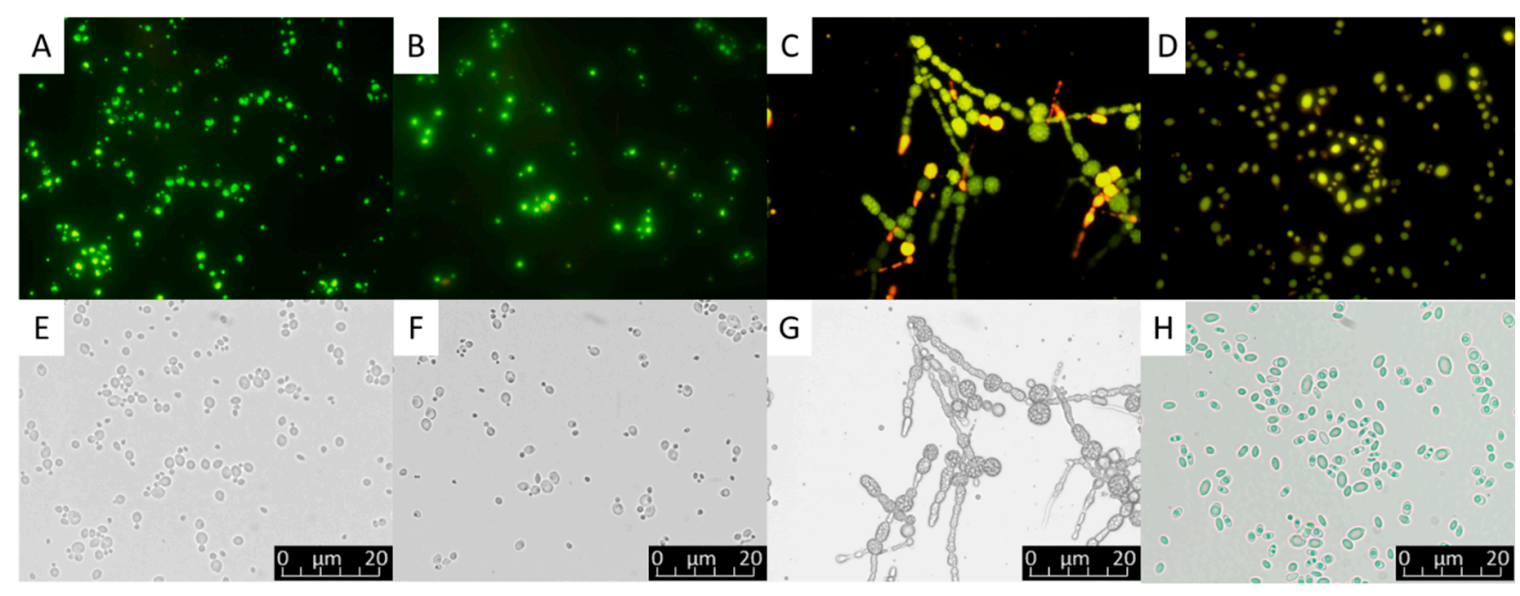

Figure 1. Lipid droplets visualized under light microscope $(400 \times)$ within yeast cells and the mycelium of a filamentous fungus as shown through fluorescent filter after Nile red staining (A-D) and without fluorescence filter (E-H). (A,E) Meyerozyma guilliermondii, (B,F) Scheffersomyces coipomensis, (C,G) Umbelopsis (Mortierella) isabellina, $(\mathbf{D}, \mathbf{H})$ Yarrowia lipolytica (Original pictures).

Oleaginous microorganisms can be found among species of microalgae, fungi (filamentous and yeasts), bacteria and protists. Microalgae strains associated with Chlorella, Scenedesmus, Chlamydomonas, Nannochloropsis, Chlorococcum, Isochrysis, Cylindrotheca, Tetraselmis, Auxenochlorella, Botryococcus species are referenced to have excellent lipid production ability [6,27-33]. Among bacteria, the known species are Rhodococcus, Streptomyces, Nocardia, Mycobacterium, Dietzia or Gordonia [34-37]. Representative oleaginous species of filamentous fungi and yeasts belong to Umbelopsis (Mortierella), Microsphaeropsis, Fusarium, Candida, Meyerozyma, Rhodotorula, Rhodosporidium, Pichia, Cryptococcus, Lipomyces, Trichosporon and Yarrowia [20,26,33,38-57].

The microbial consortia of microalgae and bacteria [58-61] or microalgae and yeast species [62-64] have been reported as a strategy to increase lipid production $[23,62]$. Although studies on consortia have shown that synergism may occur between different species, allowing increased accumulation of 
lipids, further studies are needed to determine the individual contribution of each partner to lipid production process. Since the physiology of oleaginous microorganisms varies among species [65-68], the ability to accumulate lipids is affected by different factors that are species specific.

\subsection{Growth Conditions That Promote Lipid Accumulation}

The concentration of nutrients, such as nitrogen and carbon, in culture medium is decisive for lipid production $[6,39,69-71]$.

In heterotrophs, usually a high C:N molar ratio is needed to achieve an important lipid accumulation $[4,5,47,72-74]$, while the nature of the nitrogen source plays a critical role in the process $[5,75]$. Detailed mathematical models have been developed in order to predict growth and lipid accumulation, as well as nutrient (i.e., sugar and nitrogen) consumption by oleaginous microorganisms (see for instance [74]). In some cases, ammonium nitrogen favors lipid accumulation [76], while in others, organic nitrogen is preferred for lipogenesis $[4,5,76,77]$. In addition, the limitations of minerals such as magnesium, iron, zinc, phosphorous or the double limitations of minerals including nitrogen and magnesium or nitrogen and phosphorus, induce the production of lipids $[5,78,79]$. Temperature, $\mathrm{pH}$, dissolved oxygen and culture agitation are other important variables that affect lipid accumulation [72,79]. Studies have shown low biosynthesis of unsaturated fatty acids (FAs) at temperatures above $30^{\circ} \mathrm{C}$ [47] and increased lipid accumulation under neutral and basic $\mathrm{pH}$ conditions [26]. It has been reported that biomass and lipid production are high between 200 and $300 \mathrm{rpm}$, speeds that allow for high oxygenation. However, lipid production decreases as agitation increases, while at lower agitation speeds the carbon metabolism is diverted to extracellular products such as alcohols (e.g., ethanol, mannitol, arabitol and 2,3-butanediol) [47,80].

The concentration and chemical forms of nitrogen influence the growth and lipid production in autotrophic microorganisms such as microalgae [81]. Studies have shown that many species of microalgae accumulate a greater amount of lipids, especially TAGs, under nitrogen limited conditions, compared to nitrogen excess conditions [82]. On the contrary, other studies suggest that nitrogen deficiency adversely affects photosynthesis, thus biomass production and lipid productivity, due to decreased biosynthesis of NADPH, which is the main source of reducing power $[83,84]$. Furthermore, it is possible that nitrogen limitation also affects the lipid profile and several biochemical pathways of the cells [85-87]. Therefore, new approaches, such as metabolic engineering, may be needed to increase the understanding of the effect of nitrogen on microalgae physiology and on the synthesis and accumulation of TGAs.

In many microalgae species, lipid accumulation is favored in phosphate limited conditions $[3,88]$, as well as, at $\mathrm{pH}<8$. Specifically, the dissociation of $\mathrm{NH}_{4}{ }^{+}$to $\mathrm{NH}_{3}{ }^{-}$occurs at $\mathrm{pH}>8$; thus, at lower $\mathrm{pH}$ values, nitrogen exists as $\mathrm{NH}_{4}{ }^{+}$ions, which is preferred by microalgae over $\mathrm{NH}_{3}$ [89,90]. Furthermore, studies have also demonstrated the lipid content increases with light intensity, $\mathrm{CO}_{2}$ concentration and oxidative stress caused by salinity [91-93]. Growth rate as well as the productivity and lipid composition can be affected by temperature changes [94,95]. The different factors that are involved in the growth and lipid biosynthesis in microalgae can affect the different species in different ways, so their optimum values are species- or even strain-specific and should be experimentally determined.

Recently, the effect of reactive oxygen compounds (ROS) or free radicals on the synthesis and accumulation of lipids of heterotrophic and autotrophic oleaginous microorganisms has been evaluated. ROS are generated during microbial metabolism as signs of stress and include superoxide $\left(\mathrm{O}_{2}{ }^{-}\right)$, hydroxyl $\left(\mathrm{OH}^{-}\right)$, perhydroxyl $\left(\mathrm{HO}_{2}^{-}\right)$and the alkoxy radical $\left(\mathrm{RO}^{-}\right)$, and non-radical forms such as hydrogen peroxide $\left(\mathrm{H}_{2} \mathrm{O}_{2}\right)$ and oxygen $\left(\mathrm{O}_{2}\right)$. Their accumulation usually results in lipid peroxidation and protein and DNA denaturation. However, it has been demonstrated that, at balanced levels, ROS can promote lipid synthesis [96,97], although the specific mechanisms of ROS participation in lipid synthesis are not yet fully elucidated. Thus, more research work is required to implement stress-based strategies to improve microbial lipid production. 


\subsection{Sugar Conversion into SCO and Regulatory Mechanisms in Sugar Assimilation}

The conversion of sugars and other hydrophilic substrates into SCO is done through de novo biosynthesis, which comprises three physiological phases, including the growth phase occurring under balanced conditions, the oleaginous phase occurring under nitrogen limited conditions, and the reserve lipid turnover phase occurring after the depletion of the carbon source in the growth medium. During the growth phase, oleaginous microorganisms convert the carbon source into cell mass, rich in proteins and polysaccharides using the glycolytic pathway and the pentose phosphate pathway (PPP), while limited quantities of lipids, mainly polar lipids essential for the construction of cell membranes, are synthesized [44]. Then, in the stationary growth phase, the depletion of at least one essential nutrient (e.g., nitrogen, sulfate, phosphate or magnesium), induces the beginning of the oil accumulation phase $[5,26,70]$, which extends until the carbon source is exhausted. Finally, during lipid turnover phase, TAGs are degraded to generate energy for cell maintenance and, under specific circumstances, for growth [57].

The metabolism of sugars, including hexoses and pentoses, has been extensively investigated and their theoretical stoichiometric conversion to lipids has been calculated. Oleaginous microorganisms show an efficient capacity to catabolize glucose and similar sugars to pyruvate, which is used in lipid biosynthesis. $100 \mathrm{~g}$ of glucose (about $0.56 \mathrm{~mol}$ ) yields one mol of pyruvate, which is converted into $1.1 \mathrm{~mol}$ of acetyl-coA, corresponding to a maximum theoretical value of $0.32 \mathrm{~g}$ of lipids per $\mathrm{g}$ of glucose. If xylose is considered, a yield of $1.2 \mathrm{~mol}$ of acetyl-coA per $100 \mathrm{~g}$ of xylose $(0.66 \mathrm{~mol})$ is expected, which corresponds to $0.34 \mathrm{~g}$ of lipids per $\mathrm{g}$ of substrate [98]. Although the theoretical results offer a good approximation, under real culture conditions, the lipid yield rarely exceeds $0.22 \mathrm{~g} / \mathrm{g}$ of glucose and $0.23 \mathrm{~g} / \mathrm{g}$ of xylose [2,99]. On the other hand, the efficient conversion of sugar compounds, such as cellobiose and molasses, into storage lipids, has also been reported [50,73].

The yields obtained from oleaginous microorganisms cultivated on a single sugar are not enough to predict the efficient conversion of lignocellulosic biomass into SCO production. Instead, the simultaneous assimilation of hexoses and pentoses contained in raw substrates of plant origin is necessary to achieve sustainable SCO production processes [100]. Numerous studies on oleaginous microorganisms (especially yeasts) growing on sugar mixtures have shown that the assimilation of individual sugars is sequential, starting with the easiest to degrade and passing to the most complex, demonstrating diauxic growth [101-106]. Commonly, the preferred sugars are hexoses, like glucose [50,107-109], although some species are capable in efficiently metabolizing pentoses like xylose $[50,73,101]$. Diauxic behavior is attributed to two different mechanisms that may or may not occur simultaneously. The first is catabolic repression, in which the preferred sugar causes repression in the transcription of the enzymes involved in the catabolism of other sugars, and the second is allosteric competition of the transporters, in which the transporters of the preferred sugar inhibit the transporters of the other sugars. Both phenomena result in an inefficient consumption of lignocellulosic biomass and low rates of lipid accumulation [100].

In contrast, other studies on the growth of oleaginous microorganisms on mixtures of sugars have shown the capacity of some strains to consume sugars simultaneously resulting in high lipid production. Lipid yield for oleaginous yeasts and heterotrophically growing microalgae ranges from 0.15 to $0.26 \mathrm{~g}$ per g of sugar, when glucose and xylose (or mannose) are used simultaneously as carbon substrates $[50,104,110-114]$. Furthermore, some strains can consume more than two sugars simultaneously. For instance, strains of Rhodosporidium and Pseudozyma show a simultaneous consumption of glucose, xylose and fructose [115] and glucose, xylose and arabinose, respectively [116]. Likewise, Rhodosporidium kratochvilovae and Y. lipolytica showed a simultaneous consumption of different pentoses and hexoses on mixed sugar media [117,118]. In addition, it has been recently documented that strains of Meyerozyma guilliermondii, Scheffersomyces coipomensis and Sugiyamaella paludigena isolated from decaying wood can simultaneously consume glucose, mannose and xylose, the most important sugars in lignocellulosic biomass [119]. In this research, significant simultaneous expression of several key enzymes, such as phosphoglucose isomerase, phosphomannose isomerase 
and xylulokinase, involved in glucose, mannose, and xylose metabolism, respectively, has been reported proving simultaneous sugar consumption, although a preference for glucose was always observed [119]. A simplified scheme presenting the conversion of the most important lignocellulosic sugars into storage lipids is shown in Figure 2. Simultaneous sugar consumption can be attributed to the low carrier specialization in yeast [67].

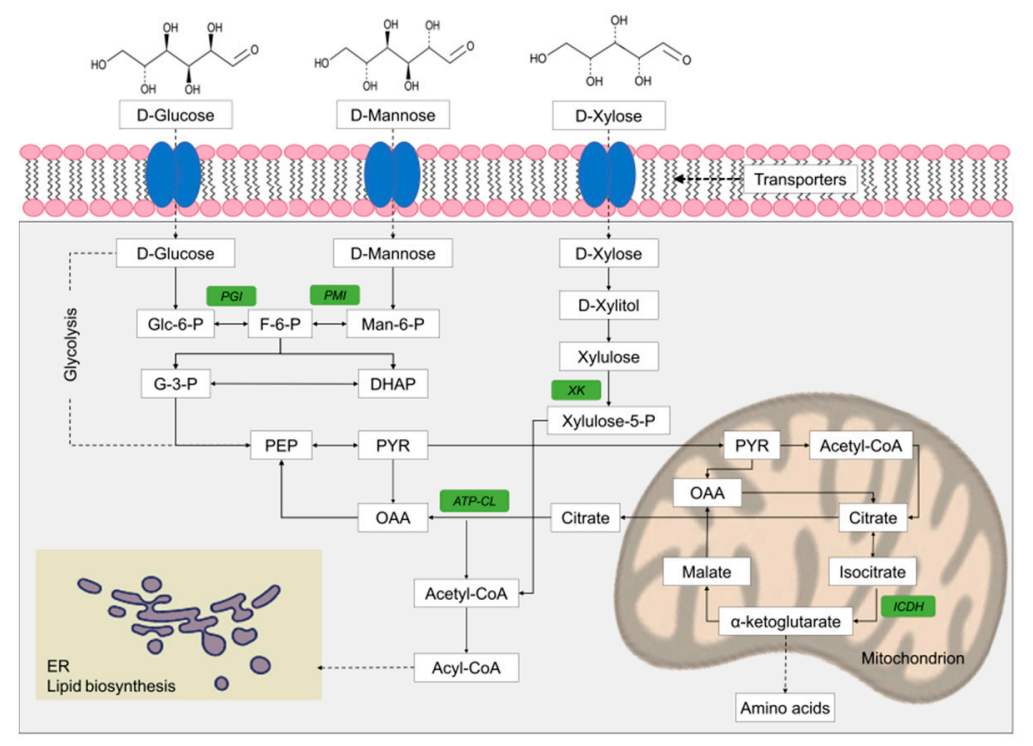

Figure 2. Simplified scheme of glucose, mannose, and xylose catabolism and principal enzymes involved in lipid biosynthesis. The key-enzymes considered in this study are highlighted in green. ICDH, $\mathrm{NAD}^{+}$-dependent isocitrate dehydrogenase; PGI, phosphoglucose isomerase; PMI, phosphomannose isomerase; XK, xylulokinase; ATP:CL, ATP citrate lyase (from Valdés et al. [119], Reproduced with permission from Applied Biochemistry and Biotechnology, Springer Nature, 2020).

Lipid accumulation is induced by nutrient (usually nitrogen) deficiency, which causes a reduction of adenosine monophosphate (AMP) concentration. This reduction inhibits NAD+-dependent mitochondrial isocitrate dehydrogenase (NAD+-ICDH), which is allosterically activated by AMP [1]. The inhibition of NAD+-ICDH causes a deregulation of the Krebs cycle resulting in citric acid accumulation in the mitochondria that is secreted then in the cytosol in exchange for malate. Subsequently, citric acid is converted to oxaloacetate and acetyl-CoA (the precursor of FA biosynthesis), through the action of ATP-dependent citrate lyase (ACL). It has been reported that a low or null activity of ICDH and a high activity of ACL in the cytoplasm are key factors for the accumulation of lipids $[2,5,6,44,119-123]$.

The process of FA synthesis is carried through the FA synthase complex. First enzyme involved is acetyl-CoA carboxylase (ACC) that converts acetyl-CoA to malonyl-CoA, reaction that frequently takes place in the cytosol of heterotrophic organisms and in the plastid of autotrophic microorganisms, and in some cases in both [3]. Then malonyl elongation is catalyzed by adding 2 carbons to the carbon chain, consuming 2 NADPH molecules per elongation unit in eukaryotes, while in autotrophic bacteria and algae the FAS type II enzyme complex catalytically elongates the lipid chains by two carbon units in an iterative pathway $[4,124,125]$. FA synthesis requires high reducing power in the form of NADPH. In oleaginous bacteria NADPH is provided by PPP [126], while in oleaginous eukaryotes NADPH is provided by both, the malic enzyme (ME) reaction that converts malate to pyruvate and the PPP [5,6,127-129]. In oleaginous microalgae the main donor of reducing power seems to be the ferredoxin NADP reductase of the photosystem I [6].

Following long chain acyl-CoA synthesis in the cytoplasm, acyl-CoA is transported to the endoplasmic reticulum (ER) and esterified with glycerol-3-phosphate (G3P), generating structural (phospholipids, glycolipids) and storage (TAG) lipids through the Kennedy pathway [5,72,130-132]. 
G3P is the second precursor molecule of TAG and therefore its availability is believed to affect TAG biosynthesis [133]. Finally, polyunsaturated fatty acids are synthesized by the action of desaturates and elongases located in the ER. In general, the lipids produced by fungi and microalgae are more unsaturated than those of yeasts.

Once the carbon source is depleted in the medium, oleaginous microorganisms use their own storage lipids as an energy source for maintenance purposes or, under certain circumstances, as carbon source for the production of new lipid-free cell material $[26,44,52]$. In the case of microalgae, lipid turnover can occur in cultures growing under $\mathrm{CO}_{2}$ starvation [27]. Lipases and hydrolases are the enzymes involved in the degradation of lipids, while the Fas released are catabolized through the process of $\beta$-oxidation towards acetyl-CoA with the participation of oxidases [44].

Significant lipid production from sugars is possible only under specific environmental conditions otherwise carbon metabolism is directed to the production of other compounds, such as low molecular weight metabolites (i.e., organic acids, sugar alcohols, ethanol, etc.) that are excreted in the growth environment. This metabolic shift may be due to the response in nutrient insufficiency, $\mathrm{pH}$ change, oxygen concentration, among other conditions [50,52,134-139].

The cost of SCO production is critically affected by the productivity of oleaginous microorganisms, especially their ability to accumulate lipids. In this context, studies using genetic engineering in the different stages of de novo synthesis and in different oleaginous microorganisms have been developed $[140,141]$. It has been shown that overexpression of genes involved in FA, G3P and TAG synthesis considerably increases lipid accumulation $[1,57,133,142,143]$. Among the over-expressed enzymes that have been shown to affect lipid accumulation are ACL [122], ACC [131,144-146], ME [147,148], FASI, FASII [149] and some desaturases [150,151].

\subsection{FA Composition of SCOs}

SCOs represent a fascinating raw material for product development because they have a chemical profile suitable for biotechnological production of biodiesel and biochemicals. The FA profile of microbial oils varies according to the genus and species [1], but usually is similar to the oils produced by oleaginous plants such as soybean, rapeseed, sunflower and palm oil [58,152,153].

SCOs produced by oleaginous yeasts and filamentous fungi mainly consist of myristic (C14:0), palmitic (C16:0), palmitoleic (C16:1), stearic (C18:0), oleic (C18:1), linoleic, (C18:2) and $\alpha$ - and $\gamma$-linolenic C18:3) acids, with C16:0, C18:1 and C18:2 usually being the most abundant Fas [2,50,57,80]. Microalgae species synthesize long-chain Fas with a higher number of double bonds, such as docosahexaenoic acid (C22:6), eicosapentaenoic acid (C20:5) and arachidonic acid (C20:4) [3,28,32,154]. Most bacteria accumulate polyhydroxyalkanoates (usually poly 3-hydroxybutyric acid), instead of TGAs [155]. The oleaginous bacteria able to accumulate TAGs are characterized by the presence of more saturated Fas, such as lauric acid (C12:0), C14:0, C16:0 and C18:0, although unsaturated Fas are sometimes present $[155,156]$.

The industrial applications of each oleaginous species are determined by its FA composition. Some microalgae and the most species of yeasts and bacteria synthesize common oils having a FA composition similar to plant oils, and thus are intended to produce biodiesel with similar physical and chemical properties to petroleum diesel $[9,28,32,66,71,154,155,157]$, while other species of microalgae and some fungi are able to synthesize polyunsaturated fatty acids and therefore are intended to produce cosmetics, infant formula additives and animal feed [28,29].

\subsection{Importance of Lignocellulosic Biomass as Raw Material}

The use of lignocellulose as substrate for oleaginous microorganisms promises a production of SCOs economically viable and sustainable [22,158]. Lignocellulosic biomass represents a fascinating raw material for producing valuable compounds because it is a renewable, abundant and inexpensive substrate $[159,160]$. It is composed of a high percentage of assimilable sugars suitable to produce biofuels or oleochemicals $[14,15,22,160]$. Most research has been focused on terrestrial lignocellulosic 
biomass; however, the use of marine lignocellulosic biomass from micro and macro algae has also been considered [161].

\subsection{Lignocellulose Structure and Chemical Composition}

Lignocellulose provides mechanical support and tolerance to biotic and abiotic stresses in plants. Its structure consists mainly of a network of cellulose, hemicelluloses (which together form the holocellulose) and lignin polymers and in less quantities starch, pectin, extractives, ashes, etc. [162-165]. The content of each of the above compounds depends on the species, tissues and age of the cells [161].

Cellulose is the most abundant polymer, representing $34-50 \%$ of the dry biomass in softwood species and $41-50 \%$ in hardwood species, while in agricultural residues ranges from 17 to $42 \%$ [161]. It is an amphiphilic and linear homopolymer composed of more than 10,000 glucose molecules linked by $\beta(1-4)$ glycosidic bonds. Specifically, between two glucose molecules the second unit rotates around the $\mathrm{C} 1-\mathrm{C} 4$ axis, forming a dimer known as cellobiose that binds to each other forming linear glucose chains [166].

Hemicelluloses are amorphous, branched heteropolysaccharides formed by a main chain and other lateral ones. The main chain is composed of the same (homopolymer) or different (heteropolymer) sugar units and is shorter in length than cellulose. The side chains are short and linked mainly by $\beta(1-4)$ glycosidic bonds and occasionally by $\beta(1-3)$, which are readily hydrolysable. Sugars can be hexoses (glucose, mannose, and galactose), pentoses (xylose and arabinose), uronic acids and deoxyhexoses (such as rhamnose and fucose) [165]. Hardwoods (i.e., angiosperms) contain mainly glucuronoxylans, while softwoods (i.e., gymnosperms) contain mainly galactoglucomannans, which represent approximately $18-35 \%$ of the lignocellulosic biomass [161,167]. In agricultural biomass, xylan is the main hemicellulose and represents between $12 \%$ and $37 \%$ of the lignocellulosic biomass [161].

Lignin is the most abundant organic polymer after cellulose, representing $19-35 \%$ of the lignocellulosic biomass of woods and $3.5-30 \%$ of grasses [161,168,169]. It is mainly formed in vascular tissues and provides mechanical resistance to xylem. Lignin is classified into three types of phenylpropane units (or monolignols), guaiacyl (G), syringyl (S) and p-hydroxyphenyl (H), derived from alcohols, coniferyl, sinapyl and p-coumaryl, respectively. In softwoods, the predominant lignin is guaiacyl, in hardwoods guaiacyl and syringyl in a ratio of 1:1 to 1:3, while all the lignin monomers are present in the grasses [170].

In addition, other biomolecules are also present in the cell wall of plants in smaller quantities. Compounds such as tannins, phenols and lignans are mostly connected to lignin and represent between $1 \%$ and $5 \%$ of lignocellulosic biomass [166]. It is also possible to find pectins and pectin-like compounds (such as galacturonans, galactans and arabinans), starch, and proteins, although they decrease as plants age. Free amino acids or alkaloids that contribute to the nitrogen content, inorganic components (e.g., $\mathrm{Ca}, \mathrm{K}, \mathrm{Mg}, \mathrm{Mn}, \mathrm{Na}, \mathrm{P}$ and $\mathrm{Cl}$ ) and trace elements (e.g., $\mathrm{Ba}, \mathrm{Al}, \mathrm{Fe}, \mathrm{Zn}, \mathrm{Si}, \mathrm{Pb}, \mathrm{Ni}, \mathrm{V}, \mathrm{Co}, \mathrm{Ag}$ and $\mathrm{Mo}$ ) essential for growth are also present [166].

Most of the highly diverse compounds found in the lignocellulosic biomass, can be metabolized by oleaginous microorganisms, but not all of them can lead to an important production of lipids. For this reason, it is essential to analyze the effect of the different lignocellulosic compounds on the metabolism of oleaginous microorganisms in order to design an efficient production process. In this sense, there is still much to be investigated experimentally.

\subsection{Recalcitrance of Lignocellulosic Biomass}

Recalcitrance of lignocellulosic biomass is linked to physical and chemical factors involved in the bonds among polymers. First, cellobiose molecules are bound through hydroxyl groups by means of hydrogen bonds to form cellulose microfibers, with a hydrophobic interior and a hydrophilic exterior. These, in turn, are joined by Vander Waals forces to form macrofibrils with highly recalcitrant regions (crystalline regions) $[166,171]$. The abundance of crystalline regions changes according to the type of plant, even among species of the same genus [162]. Macrofibrils bind to hemicelluloses and 
hemicelluloses to lignin forming a stable structure. Lignin at the molecular level controls permeability, improves the mechanical properties of the cells and protects them from microorganisms and chemical degradation, being the main factor that imparts recalcitrance to the biomass.

To reduce/eliminate recalcitrance and obtain assimilable sugars it is necessary to destabilize the cellulose, hemicelluloses and the lignin matrix. The amorphous regions of the cellulose and the branches of the hemicelluloses provide a certain degree of flexibility and susceptibility to degradation and are the key points to begin deconstructing. This goal is approached through the application of various pretreatments $[171,172]$ as described below.

\section{Conversion of Lignocellulosic Biomass into Assimilable Sugars in Nature}

In nature, degradation of lignocellulosic material can be mediated mainly by degrading animals and fungi. Insects such as wasps, ants and termites, other animals, such as beavers, rats and woodpeckers and mollusks from aquatic environments perform mechanical degradation, while decaying fungi perform enzymatic degradation $[170,173]$. Wood decay fungi have been extensively studied. They are a diverse group of species belonging mainly to the Basidiomycota and Ascomycota divisions [71]. They are saprophytes, capable of penetrating and colonizing the interior of plants with their hyphae, entering through the pores or through the ruptures of cell walls caused by enzymes that they secrete $[166,170]$.

Decomposition of wood by fungi is typically classified into three types: brown rot white rot and soft rot. Brown rot is commonly brown and crumbly and is produced by non-enzymatic and enzymatic systems. Brown rot fungi produce cellulases but not enzymes that degrade lignin. However, they possess a non-enzymatic mechanism that results in the modification of lignin and a slow depletion of lignin from wood in the process of decomposition known as the chelation-mediated Fenton system (CMF) [173,174]. White rot fungi, possessing lignin-degrading enzymes, are the only organisms capable of degrading all wood components. The capacity of these fungi to secrete non-specific ligninolytic and cellulolytic enzymes allows the transformation of a great variety of recalcitrant compounds into assimilable carbon forms, as the extracellular nature of the above enzymes allows fungi to access non-polar and insoluble compounds [175-177]. Soft rot fungi produce cavities and erosion in the cell walls of wood. Under aerobic conditions, these fungi can completely mineralize lignin and polysaccharides (cellulose, hemicelluloses) into $\mathrm{CO}_{2}$ and $\mathrm{H}_{2} \mathrm{O}$, in addition to causing wood rot [178].

The natural mechanisms usually cause degradation at low rates. However, some technologies based on natural processes, such as biopulping and biodegradation (e.g., used in the degradation of resins and dyes), have been applied to degrade lignocellulosic biomass $[177,179,180]$.

\section{Biomass Pretreatment to Decrease Recalcitrance}

To obtain assimilable sugars from lignocellulosic biomass, it is necessary to apply previous processes that include mechanical methods, physicochemical pretreatments and enzymatic hydrolysis. First, it is necessary to reduce the size of the particles in order to decrease the degree of polymerization and to increase the surface area and porosity of the biomass to improve the exposure to the action of reagents. This can be done through a mechanical process, considered a fundamental step of the lignocellulosic biorefinery, which includes processes such as cutting or grinding (the size varies from meters to centimeters), coarse grinding (from $\mathrm{cm}$ to $500 \mu \mathrm{m}$ ), intermediate micronization (from $\mathrm{cm}$ to $100 \mu \mathrm{m})$ and fine grinding $(<100 \mu \mathrm{m})$. These are generally obtained by compression friction or shearing and therefore generate a specific energy requirement (SER) that must be evaluated [71,166,181,182]. SER in mechanical treatment is affected by the moisture content and chemical composition of the substrate and has been demonstrated to increase with increasing moisture and arabinose/xylose content [183].

It has been reported that mechanical processes can increase carbohydrate production, improving yield and enzymatic hydrolysis rate by $5-25 \%$ and $23-59 \%$, respectively, compared to untreated biomass [71]. After the mechanical process, a pretreatment is applied that leads to the reduction of the 
biomass recalcitrance and, in some cases, to the hydrolysis of a significant percentage of polysaccharides. However, mechanical processes are usually intended to increase the accessible surface area of cellulose and hemicelluloses to enzymes to be used in enzymatic hydrolysis [15].

Pretreatments vary and have been widely studied in productive, technical, economic and environmental terms [184-188]. In this context, chemical pretreatments such as acid, alkaline and acid combined with alkaline have been the most preferred and patented techniques in recent years, compared to other methods. These represent advantages associated with the use of commonly used compounds, flexibility of application at the industrial level and high final yields of assimilable sugars $[171,172,186,187]$. Other recommended pretreatments are steam explosion and treatment with organosolv. Steam explosion (or autohydrolysis used as a synonym), is the most widely used physicochemical pretreatment method. It has been described as an economical and environmentally friendly method that reduces the concentration of toxic compounds in hydrolysates compared to other pretreatments, such as acid pretreatment $[48,186,189]$. Organosolv pretreatment, although more expensive than the other processes, may provide some valuable by-products that allow the sustainability of the process. In a biorefinery, organosolv pretreatment is one of the best options due to very good quality of cellulose obtained, very accessible to enzymes, and lignin residual from which it is possible to produces more than one valuable product (e.g., bioethanol and lignin products) in the same process $[163,190]$.

The selection of the pretreatment method and its operating conditions, are fundamental for a successful enzymatic hydrolysis and subsequent fermentation. The conditions used largely depend on the nature and chemical composition of the substrate (hardwood, softwood or herbaceous) and determine the amount of the generated by-products that can interfere with enzymatic hydrolysis and fermentation. Below is a description of the advantages and disadvantages of the most recommended processes (acid, alkaline, acid-alkaline, steam explosion and organosolv) and a discussion of the yields and effects of these pretreatments on enzymatic hydrolysis. Table 1 shows the most frequent values of the working conditions and yields of the different pretreatments applied to different lignocellulosic substrates. 
Table 1. Glucose (Glc), hemicelluloses (H), lignin (L) and inhibitory by-products produced after pretreatments of various lignocellulosic biomasses, as well as biomass digestibility (expressed as Glc and $\mathrm{H}$ released) after enzymatic hydrolysis.

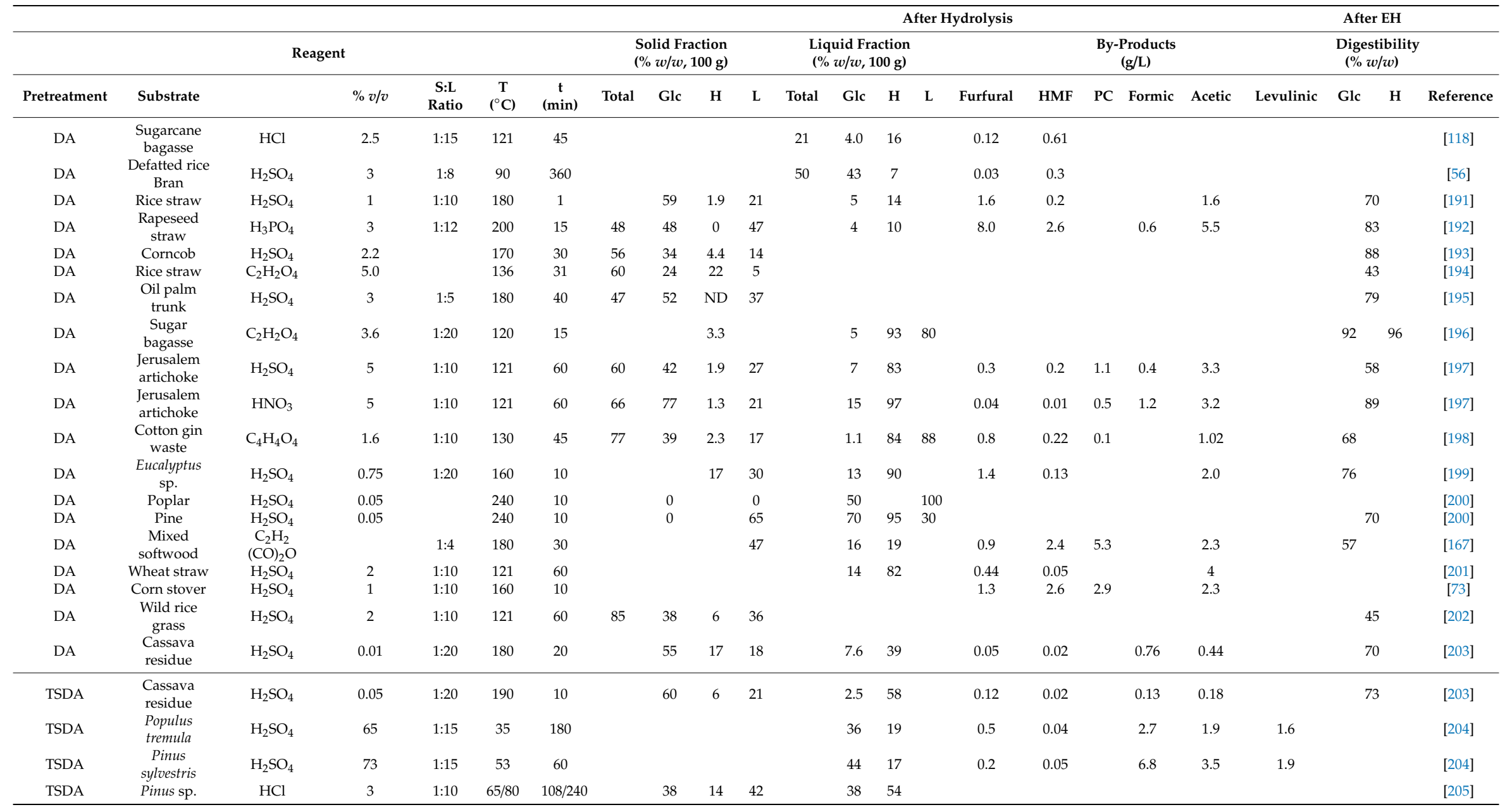


Table 1. Cont.

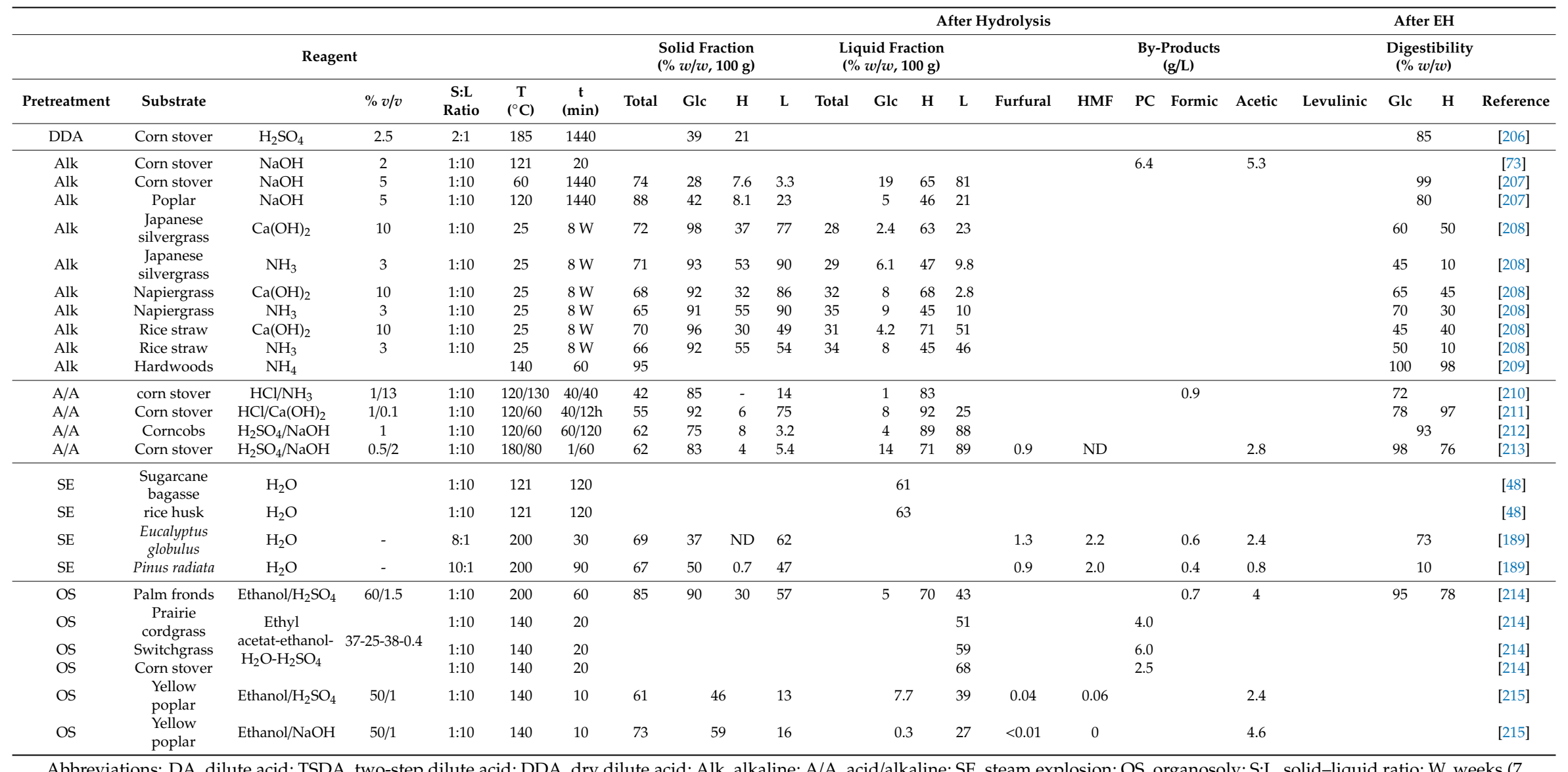

Abbreviations: DA, dilute acid; TSDA, two-step dilute acid; DDA, dry dilute acid; Alk, alkaline; A/A, acid/alkaline; SE, steam explosion;
days); $\mathrm{T}$, temperature; $\mathrm{t}$, time; Glc, glucose or glucan; $\mathrm{H}$, hemicelluloses; $\mathrm{L}$ lignin; $\mathrm{EH}$, enzymatic hydrolysis; PC phenyl compounds. 


\subsection{Principal Pretreatments}

\subsubsection{Acid Pretreatment}

Acid pretreatments are effective in breaking the lignocellulosic matrix at the glycosidic bonds between lignin and hemicelluloses, by solubilizing most of the hemicelluloses (commonly over $90 \%$ $w / w)$, as well as reducing some of the cellulose and removing part of lignin (Table 1). The process consists first in the hydrolysis of hemicelluloses to its monomeric sugars, and then in the depolymerization of the cellulose into oligosaccharides, with further release of monomeric sugars. Both steps allow for a significant increase in porosity and a significant lignin removal. However, acid pretreatment is suitable for removing lignin from hardwoods and agricultural residues, but not from softwoods. The difficulty of removing lignin from softwoods is well documented and is due to the structural characteristics of softwood lignin $[167,200]$.

The acids used can be both inorganic (e.g., phosphoric, nitric, hydrochloric or sulphuric acid) or organic (e.g., acetic, citric, maleic or oxalic acid) $[167,186,187]$, with sulphuric acid being the most commonly used. Acid pretreatment can be wet acid, using concentrated $(>30 \% w / v)$ or diluted $(<30 \% w / v)$ in water acid, or dry diluted acid, which has been recently documented $[186,187,206]$.

Pretreatment using concentrated acid is a process that makes it possible to obtain a high content of assimilable sugars $(>50 \%)$ with low energy costs since it is carried out at low temperature $\left(<100{ }^{\circ} \mathrm{C}\right)$, even at room temperature. The disadvantages of using concentrated acids are the requirement of corrosion resistant equipment that increases investment costs and the risk of the reagents, which are highly dangerous and require investment in safety issues. Additionally, concentrated acid causes a partial degradation of hemicelluloses to by-products that accumulate in the liquid waste as organic acids, furfural and 5-hydroxymethylfurfural (HMF), mostly, reporting total values even over 13 g/L [204]. These have been reported as inhibitors of enzymatic hydrolysis and fermentation. Strategies have been developed to reduce the inhibitor concentration, such as the use of two stages acid pretreatment, where a less concentrated acid is first applied to extract hemicelluloses, causing a restricted degradation, following by a more concentrated acid, aiming the cellulose destruction [204,216]. However, the disadvantages have made them less attractive processes to implement and, in this sense, diluted acid pretreatments are preferred.

Diluted acid pretreatment is less aggressive, more environmentally friendly, and less costly, given the lower acid demand [172]. In addition, it allows the recovery of much of the sugar from hemicelluloses at the end of the process, usually with a low production of inhibitory compounds (Table 1). Most pulps obtained from diluted acid are very accessible to the enzymes; therefore, it is possible to recover glucose and a cellulose solid fraction that usually has over $70 \%$ digestibility (Table 1). The disadvantage of diluted acid pretreatments is that they require higher temperatures than those used in treatments with concentrated acids, thus increasing energy costs. The release of glucose in diluted acid pretreatments has been optimized by using more than one stage, alternating high and low temperatures during short and long retention periods [205,217]. Solid catalysts may also be used in the pretreatment (e.g., carbon-based, zeolites, ion exchange resins) that can be recycled and reused several times. These improve the yields of assimilable sugars and leave a cellulose fraction that is easily hydrolysable, achieving glucose yields of more than 91\% after enzymatic hydrolysis [187,218].

Pretreatment with dry diluted acid has been proposed as an alternative to the use of diluted acid pretreatment. In this process, both the raw material and the product are generally solid. The biomass is even used at more than $70 \% w / w$ with respect to the diluted acid, which is impregnated and fully absorbed by the biomass [206]. After enzymatic hydrolysis, sugar yields similar to those obtained with diluted acid pretreatment are obtained. One of its advantages is that it produces exceptionally low concentrations of furfural and HMF in the pretreated solid ( $<0.1$ and up to $0.90 \%)$ compared to those formed in other acid pretreatments $[187,206]$. However, dry diluted acid pretreatment requires special equipment to improve impregnation and more stages in the process, while few studies have been carried out on this topic. 


\subsubsection{Alkaline Pretreatment}

Alkaline pretreatment allows a destruction of the lignocellulose and decreases both the degree of polymerization and the crystallinity of the cellulose. It is effective in extracting lignin and solubilizing a part of the hemicelluloses (commonly $>40 \% w / w$ ), while causing negligible degradation of the cellulose (Table 1). During alkaline pretreatment, the first reactions are the dissolution and saponification of the intermolecular ester and ionic bonds that cross the hemicelluloses and other components, reactions that increase the porosity of the lignocellulosic biomass through the disintegration of these bonds. In addition, hydrolysis of glycosidic bonds and acetyl groups may occur, breaking down polysaccharides and enhancing subsequent enzymatic hydrolysis $[186,219]$. The most used bases are sodium, potassium, calcium hydroxide and ammonium hydroxide $[185,219]$. In general, alkaline pretreatment is more effective on hardwoods, arable crops and agricultural residues with low lignin content than on softwoods with high lignin content [186]. Compared to other pretreatments, it is considered of low cost and its main disadvantage is the formation of salts, which are difficult to remove, and the low yields in monomeric sugar $[172,185]$. The digestibility in the solid fraction is frequently more than $70 \%$ (Table 1 ).

\subsubsection{Sequential Acid-Alkaline Pretreatment}

Some researchers have also tested the combination of both acid and alkaline pretreatment processes for significant recovery of reducing sugars. Commonly, the process involves hydrolysis using a dilute acid [15], solid extraction and washing and then treatment with dilute alkaline solution. The acidic stage allows the recovery of most hemicelluloses, that are usually above $70 \% w / w$, and the alkaline stage allows the extraction of a high percentage of lignin frequently $>80 \% w / w$ (Table 1 ). The cellulose is recovered at a rate above $75 \%$ and highly hydrolysable. Compared to diluted acid pretreatment, the proposed combined pretreatment minimizes the generation of by-products [213]. The main disadvantage is that more investment in equipment is required to develop the two stages and more processing time is needed, as the number of stages increases [172].

\subsubsection{Steam Explosion Pretreatment}

This pretreatment, being recognized as one of the most efficient processes for lignocellulosic biomass from hardwood and herbaceous, consists of treating the biomass at high pressure using water vapor and at high temperature for a short period of time and then quickly depressurizing, which generates a disruption of the biomass with the partial elimination of the lignin [15,71]. During the process, due to the acidic condition, organic compounds such as acetic acid are generated, causing the formation of acetyl groups, which allow an autohydrolysis of the hemicelluloses and a partial delignification, increasing the exposure of the cellulose to the enzymatic hydrolysis that follows $[15,186]$. It can also be used in two stages for enhanced recovery of assimilable sugars, first under milder conditions to recover hemicelluloses and then under stronger conditions to destabilize the cellulose and recover higher percentages of glucose [185]. The advantages of steam explosion pretreatment are that it has a lower environmental impact and a lower production of toxic compounds, than those of acid and alkaline processes [186]. On the other hand, this pretreatment is less effective for softwoods, as they have a low content of acetyl groups, making the use of catalysts necessary, e.g., chemical compounds such as $\mathrm{SO}_{2}, \mathrm{H}_{2} \mathrm{SO}_{4}$ and $\mathrm{CO}_{2}$ have been used to impregnate the softwood before pretreatment $[71,186]$. Nevertheless, this has the disadvantages of requiring more time for impregnation and generating greater formation of inhibitors and higher degradation of sugars [185,217]. Treatment pressure has a direct effect on reducing sugars yields, with values above $60 \% w / w$ [48].

\subsubsection{Organosolv Pretreatment}

Organosolv pretreatment involves the application of an organic solvent to the lignocellulosic biomass in order to separate lignin in the liquid fraction and cellulose in high concentrations in the 
solid residue. Pretreatment generates excision of lignin bonds, especially of O-aryl ether bonds with carbohydrates, producing a solid phase, which consists mainly of cellulose and hemicelluloses, and causing dissolution of lignin fragments [163]. It is carried out in different organic solvents (ethanol, methanol, acetic acid, formic acid, acetone, glycerol or phenol) whose concentrations generally vary from $<1 \% w / w$ to over $80 \% w / w$ [163] and is applied with or without catalysts (sulphuric acid, magnesium chloride, or sodium hydroxide). Treatment with ethanol is the most attractive and used method due to the low cost of the solvent and the high yields of extracted lignin $[163,190]$. The organosolv pretreatment of hardwood and herbaceous in aqueous solutions can generate acetic acid from the acetyl xylan groups, which in turn catalyzes the degradation of hemicelluloses, the dissolution of lignin and stimulates the autohydrolysis of cellulose [190]. Softwoods have reduced xylan content, and therefore, the alkaline catalyzed organosolv pulping has also received a lot interest [220]. The advantages of this method are that it can be applied to hard and soft woods and the solvents can be easily recovered by more than $90 \%$ causing little environmental effect [163]. The main disadvantage is the danger of ignition by concentrated solvents and the generation of various inhibitory residues that may inhibit enzymatic hydrolysis [189]. The main degradation products are G-type lignin derivatives, such as guaiacol (C6), vanillin (C6C1), vanillic acid (C6C1) and ferulic acid (C6C3), and S-type derivatives, such as syringaldehyde (C6C1) and syringic acid (C6C1) [215].

\subsection{Optimization of Principal Pretreatments}

In general, various pretreatments do not allow total recovery of the sugars that are present in the lignocellulosic biomass. On the contrary, these techniques result in yields of $90 \%$ or less of the theoretical sugar yield [215]. In this context, studies have shown that combined pretreatments improve the yield of sugars after enzymatic hydrolysis $[165,172,185,219]$. Work has been done for example on combined treatments of alkaline with ionic liquids (IL) and microwaves [221]. IL with steam explosion [189], alkaline with oxidation [113,207], acid with steam explosion [222], among others, improve sugar yield even by more than $100 \%$ compared to the application of a single pretreatment. Table 2 presents the main advantages and disadvantages of the alternative treatments that can be used in combination with the above described conventional treatments. It is also possible to use catalytic compounds that are impregnated before or during the pretreatment and improve the destruction of the cellulose, yielding shorter chains, which are easily hydrolyzed, and result in less degradation products of the cellulose and hemicelluloses monosaccharides $[71,168,187,218]$. However, these should be used in an appropriate manner, and further studies are needed to avoid negative effects, such as an increase in by-products that inhibit hydrolysis and fermentation. 
Table 2. Features of different pretreatments utilized to improve the efficacity of conventional pretreatment (acid, alkaline, acid/alkaline, steam explosion and organosolv).

\begin{tabular}{|c|c|c|c|c|c|}
\hline Pretreatment & Advantage & Disadvantages & Action Mechanism & Work Condition & References \\
\hline Ionic liquids (IL) & $\begin{array}{c}\text { Applied with alkaline pretreatment } \\
\text { Environmentally friendly } \\
\text { Decreases crystallinity and increases porosity } \\
\text { Up to } 90 \% \text { assimilable sugars are obtained after } \\
\text { enzymatic hydrolysis }\end{array}$ & $\begin{array}{c}\text { Expensive liquids } \\
\text { Residual IL interfere with } \\
\text { enzymatic hydrolysis }\end{array}$ & $\begin{array}{l}\text { Cleavage of the } \beta \text {-O- } 4 \text { bonds in lignin } \\
\text { followed by dipole-ion formation. Cellulose } \\
\text { is destabilized, and hemicelluloses are } \\
\text { dissolved. IL are composed by organic } \\
\text { cations and small inorganic or organic } \\
\text { anions, linked by a strong ionic bond. } \\
\text { Commonly IL used are imidazonium salts, } \\
\text { AMIMCl (1-Allyl-3-methylimidazonium } \\
\text { chloride) and BMIMCl } \\
\text { (1-butyl-3-methylimidazolium chloride) }\end{array}$ & $\begin{array}{l}80-160{ }^{\circ} \mathrm{C} \\
3-50 \% \text { solid } \\
30 \mathrm{~min}-8 \mathrm{~h} \\
60-80 \% \text { w/w }\end{array}$ & $\begin{array}{c}{[13,165,185,} \\
189,221 \\
223]\end{array}$ \\
\hline AFEX & $\begin{array}{c}\text { Partial disruption of the fibers leaving short } \\
\text { cellulose chains and disrupt lignin } \\
\text { Solid } 99 \% \text { recovered } \\
\text { Low inhibitor concentration } \\
\text { Removes acetyl groups by deacetylation } \\
\text { Herbaceous biomass and agricultural residues } \\
\text { are high susceptible } \\
\text { Lignin removed }>85 \% \\
\text { Up to } 95 \% \text { assimilable sugars are obtained after } \\
\text { enzymatic hydrolysis }\end{array}$ & $\begin{array}{l}\text { Hardwood low susceptible } \\
\text { Not suitable for softwoods } \\
\text { The dosage of liquid ammonia } \\
\text { is } 1-2 \mathrm{~kg} \text { of ammonia/kg of dry } \\
\text { biomass, which increases the } \\
\text { costs } \\
\text { Residual lignin generates } \\
\text { unspecific bonds in the } \\
\text { enzymatic hydrolysis }\end{array}$ & $\begin{array}{c}\text { Alkaline reagent is impregnated into the } \\
\text { biomass, pressure is applied, and it quickly } \\
\text { depressurizes Anhydrous liquid or gaseous } \\
\text { ammonia }\end{array}$ & $\begin{array}{l}60-200^{\circ} \mathrm{C} \\
10-50 \% \text { solid } \\
5-60 \mathrm{~min} \\
>100 \% \mathrm{w} / \mathrm{w}\end{array}$ & $\begin{array}{l}{[13,71,165,} \\
185,188, \\
217,224]\end{array}$ \\
\hline $\begin{array}{l}\text { Ammonia recycled } \\
\text { percolation (ARP) and } \\
\text { Soaking in aqueous } \\
\text { ammonia (SAA) }\end{array}$ & $\begin{array}{l}\text { Significant degree of delignification in } \\
\text { hardwood and herbaceous woods } \\
\text { Solids } 99 \% \text { recovered } \\
\text { Used to preserve most of the glucan and xylan }\end{array}$ & High cost due to the solvent & Solubilization of hemicelluloses and lignin & $\begin{array}{l}140-210^{\circ} \mathrm{C} \\
10-90 \mathrm{~min} \\
5-15 \% \mathrm{w} / \mathrm{w}\end{array}$ & $\begin{array}{c}{[184,188,} \\
217]\end{array}$ \\
\hline $\mathrm{CO}_{2}$ explosion & $\begin{array}{l}\text { Efficient to removing lignin in hard and } \\
\text { softwoods and to dissolving cellulose and } \\
\text { hemicelluloses } \\
\text { No inhibitory compounds have been reported } \\
\text { Low-cost pretreatment } \\
\text { Acceptable environmental impact } \\
\text { More cost-effective treatment than AFEX and } \\
\text { less toxic than steam explosion }\end{array}$ & $\begin{array}{l}\text { Lower yield than steam and } \\
\text { AFEX explosion }\end{array}$ & $\begin{array}{l}\text { Supercritical fluid, reacting with the } \\
\text { moisture in the substrate to form carbonic } \\
\text { acid that contributes to the degradation of } \\
\text { the biomass }\end{array}$ & $\begin{array}{l}31-250^{\circ} \mathrm{C} \\
20-60 \mathrm{~min} \\
5-15 \% \mathrm{w} / \mathrm{w}\end{array}$ & $\begin{array}{c}{[71,185,186,} \\
217]\end{array}$ \\
\hline
\end{tabular}


Table 2. Cont

\begin{tabular}{|c|c|c|c|c|c|}
\hline Pretreatment & Advantage & Disadvantages & Action Mechanism & Work Condition & References \\
\hline Hot water & $\begin{array}{l}\text { Reduces the size of particles } \\
\text { Effective for solubilizing hemicelluloses as } \\
\text { oligomers } \\
\text { not require catalysts, chemical products or } \\
\text { corrosion-resistant materials } \\
\text { Lignin removed }>73 \% \\
\text { Up to } 95 \% \text { assimilable sugars are obtained after } \\
\text { enzymatic hydrolysis } \\
\text { Inhibitor compounds in low concentrations } \\
\text { compared to acid treatments. }\end{array}$ & $\begin{array}{l}\text { Inhibitors can be produced } \\
\text { requires a high demand for } \\
\text { water and energy }\end{array}$ & $\begin{array}{c}\text { Consists in cooking the lignocellulosic } \\
\text { biomass in water at high temperature and } \\
\text { pressure }\end{array}$ & $\begin{array}{l}121-240{ }^{\circ} \mathrm{C} \\
10-20 \% \text { solid } \\
4-60 \text { min }\end{array}$ & $\begin{array}{c}{[12,71,185,} \\
225,226]\end{array}$ \\
\hline Oxidative (Wet oxidation & $\begin{array}{c}\text { Used with alkaline solution }(\mathrm{NaOH}) \text { reducing } \\
\text { inhibiting products } \\
\text { Combination with stem exploitation the } \\
\text { conversion of cellulose and hemicelluloses is } \\
\text { increased } \\
\text { Removes hemicelluloses and lignin (between } \\
50-70 \% \text { ). } \\
\text { Xylan from hardwoods and herbaceous are } \\
\text { affected } \\
\text { Lignin removed }>60 \% \\
\text { Up to } 95 \% \text { assimilable sugars are obtained after } \\
\text { enzymatic hydrolysis }\end{array}$ & $\begin{array}{c}\text { Mannans from softwoods are } \\
\text { low affected } \\
\text { Cellulose is not affected } \\
\text { Possibility of non-selective } \\
\text { oxidation causing loss of } \\
\text { hemicelluloses and cellulose } \\
\text { components } \\
\text { Large amount of acids and } \\
\text { chemical compounds are } \\
\text { generated } \\
\text { High temperatures and } \\
\text { pressure and oxidizing agents } \\
\text { are costly }\end{array}$ & $\begin{array}{l}\text { When the biomass is suspended in water, the } \\
\text { oxide agents produce electrophilic } \\
\text { substitution chain reactions that divide the } \\
\text { aromatic lignin nuclei or the bonds between } \\
\text { the alkyl and aryl groups } \\
\text { Mainly degrades lignin by attacking } \\
\text { aromatic ring. } \\
\text { Oxide agents such as oxygen }\left(\mathrm{O}_{2}\right) \text {, hydrogen } \\
\text { peroxide }\left(\mathrm{H}_{2} \mathrm{O}_{2}\right) \text { or peracetic acid, ozone } \\
\qquad\left(\mathrm{O}_{3}\right)\end{array}$ & $\begin{array}{l}25-195^{\circ} \mathrm{C} \\
10-20 \mathrm{~min} \\
1-2 \% w / v\end{array}$ & $\begin{array}{l}{[71,185,} \\
210]\end{array}$ \\
\hline Microwave pretreatment & $\begin{array}{c}\text { Applied to acids and alkaline and steam } \\
\text { exploitation } \\
\text { Low cost } \\
\text { Short reaction times } \\
\text { Change ultra-structure of cellulose by degrading } \\
\text { lignin and hemicelluloses } \\
\text { Homogeneous heating of the reaction mixture } \\
\text { Improve the recovery yields of glucose, xylose, } \\
\text { and total sugar by } 13-27 \%, 17-25 \% \text {, and } 20-21 \% \text {, } \\
\text { respectively }\end{array}$ & $\begin{array}{l}\text { Increase the formation of } \\
\text { inhibitors }\end{array}$ & $\begin{array}{l}\text { Consists in radiating energy that accelerates } \\
\text { the molecules, which begin to friction each } \\
\text { other and quickly increasing the medium } \\
\text { temperature generating physical, chemical, } \\
\text { or biological reactions }\end{array}$ & $\begin{array}{l}150-180^{\circ} \mathrm{C} \\
3 \mathrm{~min} \\
1-2 \% w / v\end{array}$ & $\begin{array}{l}{[143,189} \\
227]\end{array}$ \\
\hline
\end{tabular}




\section{Pretreatment By-Products Affecting Enzymatic Hydrolysis and Fermentation}

By-products generated during the pretreatment of lignocellulosic biomass are detrimental to sugar yield and also in certain concentrations may reduce the efficiency of enzymatic hydrolysis, as well as the growth and metabolism of most microorganisms used in fermentations. Specifically, several compounds derived from lignocellulose pretreatment, even at low concentrations, can inhibit growth and lipid accumulation in oleaginous microorganisms $[15,73,191]$. Therefore, it is necessary to study the inhibitory effects, in order to adopt appropriate strategies for the production of SCO from lignocellulosic hydrolysates. The type and concentrations of each compound generated in principal pretreatments depend on the operating conditions and the composition of the biomass used (Table 1).

Among the inhibitory compounds derived from sugars are furan aldehydes, such as furfural and 5-hydroxymethylfurfural (5-HMF), generated in acidic media from the dehydration of pentoses and hexoses, respectively. Both compounds have a significant effect on enzymatic hydrolysis at concentrations of $2.0 \mathrm{~g} / \mathrm{L}$ for furfural and $4.0 \mathrm{~g} / \mathrm{L}$ for HMF [203]. In addition, research has shown that furfural and 5-HMF inhibit the metabolism of alcohol-producing yeasts, prolonging the lag phase, inhibiting cell growth and decreasing ethanol productivity. For instance, furfural is found to directly inhibit alcohol dehydrogenase, aldehyde dehydrogenase, pyruvate dehydrogenase and some enzymes involved in glycolysis [228,229]. Additionally, it is known to induce DNA damage or breakdown, inhibit protein and RNA synthesis [172,230-232], and affect the production of NADH and NADPH, decreasing the uptake rates of specific sugar [232].

Other inhibitory compounds derived from sugars are aliphatic carboxylic acids such as acetic acid, formic acid and levulinic acid. Acetic acid is formed by acid hydrolysis of hemicellulose acetyl groups, levulinic acid is the terminal product of hexose oxidation and formic acid has two pathways of formation, one by the oxidation of pentoses and the other by the oxidation of hexoses $[15,233,234]$. These acids cause a $\mathrm{pH}$ decrease which negatively affects the microbial metabolism, e.g., acetic acid can penetrate the cell membrane in its undissociated form inhibiting product formation, causing $\mathrm{pH}$ imbalances at high concentrations and eventually cell growth inhibition or death [172]. These compounds are mainly generated during acid, alkaline and organosolv pretreatment [50,108,235], and are commonly produced within a range of $0.1-5 \mathrm{~g} / \mathrm{L}$ (Table 1 ), while being especially toxic to microorganisms at concentrations ranging between 0.3 and $5 \mathrm{~g} / \mathrm{L}$ (Table 3). Regarding acetic acid, due to the low content of acetyl groups present in softwoods, pretreatments generate lower concentrations of acetic acid, while in hardwoods and agricultural residues with high acetyl group content, the concentration of acetic acid is higher resulting in an important inhibition effect [15]. In contrast, the low concentrations of acetic acid in pretreated softwood stimulate ethanol production due to the lower yeast biomass formation. This is due to the increased ATP demand and/or inefficient ATP production due to uncoupling of the respiratory chain and the oxidative phosphorylation of ADP, which leads to increased ATP-generating glycolytic activity at the expense of cell proliferation [15]. 
Table 3. Inhibition of growth and lipid production by oleaginous microorganisms due to the inhibitors generated during the pretreatment of lignocellulosic biomass.

\begin{tabular}{|c|c|c|c|c|c|c|c|c|c|c|c|c|c|c|c|c|c|c|c|c|c|c|c|c|c|}
\hline \multirow[b]{4}{*}{ Microorganism } & \multicolumn{6}{|c|}{ Furan Compounds } & \multicolumn{9}{|c|}{ Phenolic Compounds } & \multicolumn{9}{|c|}{ Weak Acids } & \\
\hline & \multirow{3}{*}{$\begin{array}{r}\mathrm{g} / \mathrm{L} \\
\mathrm{S}\end{array}$} & \multicolumn{2}{|c|}{ urfural } & \multicolumn{3}{|c|}{ 5-HMF } & \multicolumn{3}{|c|}{ Vanillin } & \multicolumn{3}{|c|}{ Syringaldehyde } & \multicolumn{3}{|c|}{ 4-HB } & \multicolumn{3}{|c|}{ Formic } & \multicolumn{3}{|c|}{ Acetic } & \multicolumn{3}{|c|}{ Levulinic } & \\
\hline & & \multicolumn{2}{|c|}{$\begin{array}{c}\% \\
\text { Inhibition } \\
(w / w)\end{array}$} & \multirow{2}{*}{$\begin{array}{c}\mathrm{g} / \mathrm{L} \\
\mathrm{S}\end{array}$} & \multicolumn{2}{|c|}{$\begin{array}{c}\% \\
\text { Inhibition } \\
(w / w)\end{array}$} & \multirow{2}{*}{$\begin{array}{c}\mathrm{g} / \mathrm{L} \\
\mathrm{S}\end{array}$} & \multicolumn{2}{|c|}{$\begin{array}{c}\% \\
\text { Inhibition } \\
(w / w)\end{array}$} & \multirow{2}{*}{$\begin{array}{c}\mathrm{g} / \mathrm{L} \\
\mathrm{S}\end{array}$} & \multicolumn{2}{|c|}{$\begin{array}{c}\% \\
\text { Inhibition } \\
(w / w)\end{array}$} & \multirow{2}{*}{$\begin{array}{c}\mathrm{g} / \mathrm{L} \\
\mathrm{S}\end{array}$} & \multicolumn{2}{|c|}{$\begin{array}{l}\text { \%Inhibition } \\
(w / w)\end{array}$} & \multirow{2}{*}{$\frac{\mathrm{g} / \mathrm{L}}{\mathrm{S}}$} & \multicolumn{2}{|c|}{$\begin{array}{c}\% \\
\text { Inhibition } \\
(w / w)\end{array}$} & \multirow{2}{*}{$\begin{array}{c}\mathrm{g} / \mathrm{L} \\
\mathrm{S}\end{array}$} & \multicolumn{2}{|c|}{$\begin{array}{c}\% \\
\text { Inhibition } \\
(w / w)\end{array}$} & \multirow{2}{*}{$\begin{array}{c}\mathrm{g} / \mathrm{L} \\
\mathrm{S}\end{array}$} & \multicolumn{2}{|c|}{$\begin{array}{c}\% \\
\text { Inhibition } \\
(w / w)\end{array}$} & \multirow[b]{2}{*}{ Ref } \\
\hline & & $x$ & $\mathbf{L}$ & & $x$ & $\mathrm{~L}$ & & $x$ & $\mathbf{L}$ & & $x$ & $\mathbf{L}$ & & $x$ & $\mathrm{~L}$ & & $x$ & L & & $x$ & $\mathbf{L}$ & & $x$ & $\mathbf{L}$ & \\
\hline $\begin{array}{l}\text { Cryptococcus } \\
\text { curvatus }\end{array}$ & 1 & - & 62 & 3 & - & 7.9 & - & - & - & - & - & - & - & - & - & - & - & - & - & - & - & - & - & - & [201] \\
\hline $\begin{array}{l}\text { Trichosporon } \\
\text { dematis }\end{array}$ & 4 & - & 59 & 2 & - & 22 & 1.2 & 71 & 80 & 1 & 88 & 98 & 1.5 & 100 & 100 & 4 & 100 & - & $>9$ & 30 & 57 & 10 & 27 & 54 & [73] \\
\hline $\begin{array}{l}\text { Trichosporon } \\
\text { cutaneum }\end{array}$ & 1 & 40 & 30 & 2 & - & - & 2 & 26 & 21 & - & - & - & 1.5 & 42 & 38 & 5 & 38 & 7 & 5 & 25 & 59 & 10 & - & - & [235] \\
\hline $\begin{array}{l}\text { Rhodosporidium } \\
\text { toruloides }\end{array}$ & - & - & - & - & - & - & 2 & 100 & - & 2.2 & 16 & - & 1.2 & 100 & - & 4 & 40 & - & - & - & - & - & - & - & [236] \\
\hline $\begin{array}{l}\text { Rhodosporidium } \\
\text { toruloides }\end{array}$ & $>1$ & 50 & - & - & - & - & $>2$ & 50 & - & - & - & - & - & - & - & 4 & 50 & - & 15 & 50 & - & - & - & - & [229] \\
\hline $\begin{array}{c}\text { Lipomyces } \\
\text { starkeyi }\end{array}$ & 1.4 & 100 & - & - & - & - & - & - & - & - & - & - & - & - & - & - & - & - & 3.9 & 100 & - & - & - & - & [237] \\
\hline $\begin{array}{l}\text { Trichosporon } \\
\text { cutaneum }\end{array}$ & 0.5 & 65 & 91 & 5 & 35 & 25 & 2 & 40 & 40 & 2.5 & 20 & 20 & 2 & 50 & 50 & 6 & 18 & 26 & 25 & 50 & 34 & 10 & 50 & 50 & [146] \\
\hline $\begin{array}{l}\text { Trichosporon } \\
\text { mycotoxinivorans }\end{array}$ & 1 & 47 & - & 2.5 & 15 & - & - & - & - & - & - & - & - & - & - & - & - & - & 2 & 0 & - & - & - & - & [50] \\
\hline $\begin{array}{l}\text { Rhodosporidium } \\
\text { fluviale }\end{array}$ & 0.3 & 75 & 87 & 2 & 75 & 0 & 0.5 & 92 & 0 & - & - & - & - & - & - & 0.5 & 100 & 100 & 1 & 72 & 97 & - & - & - & [104] \\
\hline
\end{tabular}

Abbreviations: \% Inhibition, reduction due to the inhibitory effect in respect to yields observed in cultures without inhibitors; S, substrate; X, biomass, L, lipids. 
Other sugar derivatives formed during acid pretreatment include polyols generated during the hydrogenation of cellulose and hemicelluloses sugars, such as sorbitol, mannitol, xylitol, galactitol, arabitol, ribitol (adonitol) and erythritol $[238,239]$. However, these compounds usually have no negative effect. On the contrary, it has been suggested that polyols may mimic water and maintain an artificial sphere of hydration around macromolecules and also act as scavengers of reactive oxygen species, thereby preventing lipid peroxidation [238].

Aromatic carboxylic acids derived from lignin are also generated during pretreatment, but in lower amounts. These compounds, represented by cinnamic and benzoic acid derivatives, are commonly produced from herbaceous lignin rather than hardwood and softwood lignin. The common cinnamic acid derivatives include p-coumaric, ferulic and sinapic acids. Benzoic acid derivatives include 4-hydroxybenzoic acid. Additionally, by-products from lignin are three typical aliphatic phenolic aldehydes, namely vanillin, syringaldehyde and 4-hydroxybenzaldehyde, which can also be considered as lignin derivatives of the guaiacyl group $(\mathrm{G})$, syringyl group $(\mathrm{S})$ and hydroxyphenyl group $(\mathrm{H})$, respectively $[15,73,109]$. Aromatic carboxylic compounds derived from lignin are present in hydrolyzed lignocellulosic biomass in relatively low concentrations compared to carbohydrate degradation products, such as aliphatic carboxylic acids and furan aldehydes. However, their inhibitory effect is usually stronger than aliphatic carboxylic acids, causing a loss of integrity of biological membranes, thus affecting their ability to serve as selective barriers and enzyme matrices [232]. Among phenolic compounds, vanillin is the most toxic inhibitor for microorganisms $[15,232,235]$. Phenolic aromatic compounds can also affect enzymatic hydrolysis. Although the treatment of lignocellulosic hydrolysate with reducing agents, such as bisulfite and dithionite, decreases inhibitory effects due to sulfonation of phenolics, aromatic compounds remain a problem for cellulolytic enzyme activity. It has also been shown that the inhibitory effect of phenolic compounds increases with increasing hydrophobicity [239].

The effect of the pretreatment by-products on microorganisms has been widely studied in the case of ethanol-producing microorganisms. However, since different yeasts have different responses to inhibitors, the effect of the various inhibitory compounds on microbial metabolism merits further investigation in oleaginous species. It has been shown that most oleaginous microorganisms are sensitive to the inhibitory by-products generated during lignocellulosic biomass pretreatment, although at appropriate concentrations, some of them can assimilate and/or degrade part of the by-products $[146,223,240-242]$. Table 3 shows the effect of important inhibitory compounds on the growth of oleaginous microorganisms and their ability to produce lipid.

Some by-products, especially acetic acid, have been considered as potential substrates/co-substrates or stimulators for the production of lipids by various oleaginous microorganisms, including Cutaneotrichosporon curvatum (Cryptococcus curvatus), Cyberlindnera (Williopsis) saturnus, Umbelopsis (Mortierella) isabellina, Lipomyces lipofer, Rhodotorula (Rhodosporidium) toruloides and Yarrowia lipolytica $[49,104]$. For instance, Poontawee et al. showed that the addition of acetic acid in concentrations ranging from 0.1 to $0.25 \mathrm{~g} / \mathrm{L}$ improved lipid accumulation compared to the control [104].

\section{Enzymatic Hydrolysis}

Enzymatic hydrolysis of lignocellulose after pretreatment is the last step before fermentation. The most commonly used enzymes are cellulases and hemicellulases, which convert cellulose and hemicelluloses into glucose and a mixture of pentoses and hexoses, respectively [243]. Additionally, mixtures of cellulases (Celluclast 1.5L, Sigma-Aldrich, St. Louis, MO, USA) and $\beta$-glucosidase (Novozyme 188, Sigma-Aldrich, St. Louis, MO, USA) have also been commercialized [213,244]. Cellulases represent a group of at least 15 protein families and some subfamilies that are mainly divided into endo- and exo-glucanases types and $\beta$-glucosidases. Endoglucanases attack the amorphous and low crystallinity regions of cellulose leaving a reducing and a non-reducing end, exo-glucanases attack the free ends and release cellobiose molecules and $\beta$-glucosidases break the $\beta-1,4$-D links of cellobiose, releasing glucose molecules. On the other hand, hemicellulases carry out a complete degradation of 
hemicelluloses and include a diverse group of enzymes, such as endo- $\beta-1,4$-xylanase that produces xylo-oligosaccharides and $\beta$-xylanase that breaks down xylan to produce xylose. Other accessory enzymes include $\alpha$-glucuronidase acetylxylan esterase, ferulic acid esterase, $\alpha$-galactosidase and $\alpha$-L-arabinofuranosidase, which aid in the hydrolysis of hemicelluloses side chains [71]. The synergistic action of cellulases and hemicelluloses increases the conversion rate of cellulose and hemicelluloses into free sugars.

Enzymatic hydrolysis may be inefficient due to the numerous factors that negatively affect enzyme activity. Among the factors that have been reported are the high concentration of assimilable sugars in the media, the presence of inhibitory compounds generated during chemical or physical pretreatments [245], and the long residence time, which increases non-specific and irreversible binding of enzymes with residual lignin. In general, the pretreated biomass from softwood presents more non-specific and irreversible binding of the enzymes than hardwood, due to the high residual lignin content, requiring relatively higher enzyme loads for enzymatic hydrolysis.

Increased enzyme specificity and activity, along with reduced cost of enzymes, is one of the main challenges that must be faced in enzymatic hydrolysis. Currently, work is being done to increase the digestibility of cellulose and decrease non-specific functions by adding non-ionic bases or surfactants such as polyethylene glycol and sorbitol ester and polyethoxylated, Tween-80, Tween-20, dodecylbenzenesulfonic acid, Triton X-100 and PEG 4000, which have proven to be highly effective $[47,71,186,246]$.

On the other hand, biotechnological solutions are continuously being proposed, e.g., genes encoding for cellulases have been cloned in fungi and yeasts, bacteria, and plants to understand their function and construct new sources for enzyme production [247,248]. Likewise, phytopathogens, having the ability to degrade plant cell walls, such as Fusarium verticillioides, Pycnoporus sanguineus and Chrysoporthe cubensis, are of high interest from the perspective of biotechnological production of enzymes [17].

On the other hand, simultaneous enzymatic hydrolysis (saccharification) and fermentation (SSF) seems to be a great alternative in terms of lignocellulosic material conversion that can decisively reduce the processing costs. This approach integrates the release of sugars and the biosynthesis of the microbial metabolite production in a single stage, reducing the processing time, the necessary enzymatic load, the equipment and the contamination risk and resulting in a higher product yield, compared to the separate stages [248,249]. Examples of SCO production through SSF include (a) Cryptococcus curvatus, cultivated in the presence of cellulase and cellobioses on corn biomass pretreated with IL, resulting in a lipid yield that reached $112 \mathrm{mg}$ of lipid/g of corn stover [250], (b) Trichosporon cutaneum cultivated in the presence of cellulase on pretreated with diluted acid and biodetoxified corn stover, producing more than $3 \mathrm{~g} / \mathrm{L}$ lipids [251], (c) Microsphaeropsis sp. Cultivated in the presence of cellulase in solid state fermentation on a substrate consisting of steam-exploded wheat straw and wheat bran, producing $74 \mathrm{mg}$ of lipid/g of dry substrate [252], (d) Rhodococcus opacus grown in the presence of a mixture of cellulase and $\beta$-glucosidase on diluted acid pretreated residues of pine, poplar and switchgrass, producing approximately $15 \mathrm{mg} / \mathrm{L}$ of lipids [253].

For a satisfactory SSF, it is necessary to optimize several parameters, such as the $\mathrm{pH}$, the percentage of sugars and the dose of enzymes, so as to obtain the higher possible yields at the lower costs. Temperature is another key factor to consider, since saccharification and fermentation are optimal at different temperatures [254,255]. In this context, the use of thermotolerant microorganisms capable of producing significant lipid amounts at elevated temperatures of approximately $40{ }^{\circ} \mathrm{C}$ has been proposed, since at this temperature the enzymatic hydrolysis of cellulose is more efficient. However, the accumulation of lipids by the mesophilic microorganisms is usually reduced at such a high temperature $[250,256]$. 


\section{SCO Production from Hydrolyzed Lignocellulosic Biomass}

The production of SCO by oleaginous species, principally yeasts, filamentous fungi and bacteria, cultivated on lignocellulosic hydrolysates has been studied by many authors, (selected papers are included in Table 4). Likewise, in recent years, the conversion of lignocellulosic hydrolysates into SCO by heterotrophically growing oleaginous microalgae, such as the green microalgae Auxenochlorella (Chlorella) protothecoides has been studied [257]. Based on the information included in the current review and taking into account the International Patent WO 2015/162568 Al, a flow chart was designed showing the various stages of an industrial process for the production of microbial oils by cultivating oleaginous microorganisms on lignocellulose substrates (Figure 3).

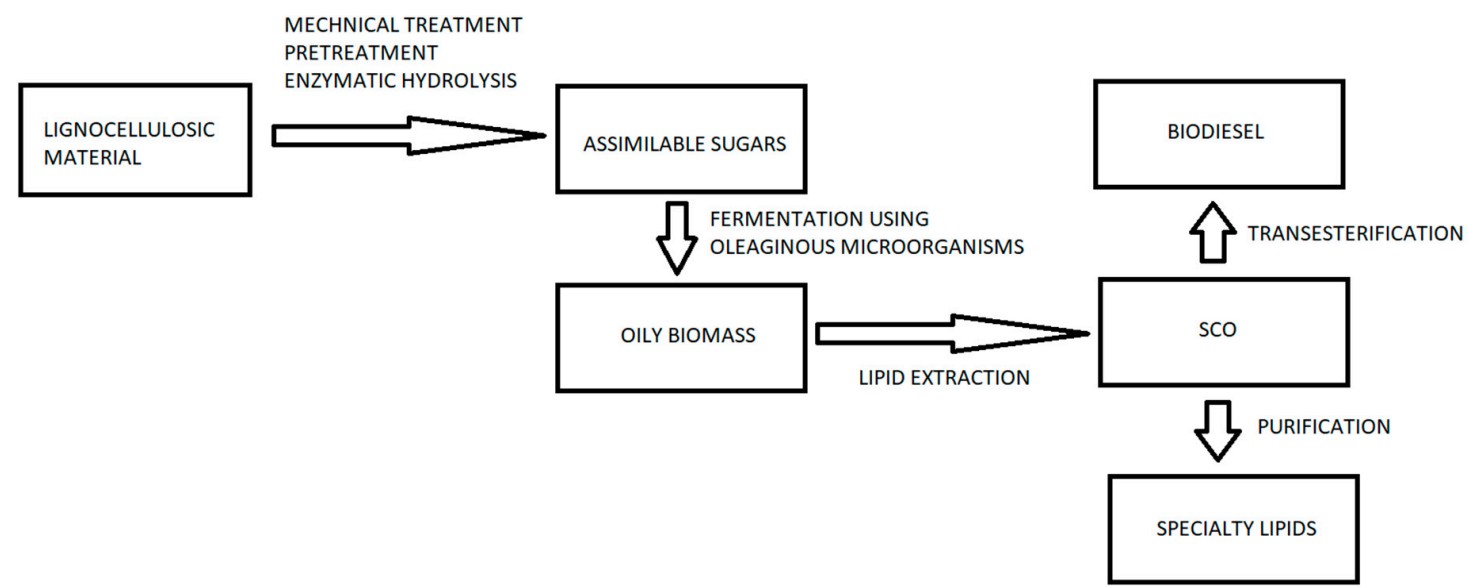

Figure 3. A simplified flow chart of an industrial process for the production of lipids from lignocellulosic biomass using oleaginous microorganisms.

In addition to the general conditions required for SCO production by oleaginous microorganisms, their cultivation in lignocellulosic hydrolysates may require additional treatment of the substrate, e.g., detoxification, due to the presence of inhibitory compounds generated during pretreatment. Nevertheless, some microorganisms are able to grow well even on undetoxified hydrolyzed lignocellulosic media and accumulate satisfactory amounts of lipids. Biomass and lipid production by selected oleaginous microorganisms, cultivated in both detoxified and undetoxified lignocellulosic hydrolysates (DLH and ULH, respectively) derived from different plant biomasses are show in Table 4 .

Several investigations have shown that inhibitory compounds generated during lignocellulosic biomass pretreatment negatively affect growth and lipid production (Table 3), making the application of additional treatments often necessary to reduce toxicity. A conceptual scheme proposed for SCO production using lignocellulosic hydrolysates as substrate is shown in Figure 4. 
Table 4. Growth and lipid production by oleaginous microorganisms cultivated on lignocellulosic hydrolysates.

\begin{tabular}{|c|c|c|c|c|c|c|c|c|c|c|c|c|}
\hline Microorganism & Strain & Biomass & Pretreatment & Sy & & ULH/DLH & $S(g / L)$ & $X(g / L)$ & $\mathrm{L} \%(w / w)$ & $\mathrm{L}(\mathrm{g} / \mathrm{L})$ & $\mathrm{L}(\mathrm{g} / \mathrm{g})$ & Reference \\
\hline \multicolumn{13}{|l|}{ Yeasts } \\
\hline Trichosporon dematis & CH007 & Corncob & DA & batch & flask & DLH & 42 & 17 & 40 & 7 & 0.16 & [258] \\
\hline Cryptococcus curvatus & ATCC 20509 & Wheat straw & DA & batch & & ULH & 29 & 17 & 34 & 5.8 & & [201] \\
\hline Cryptococcus curvatus & ATCC 20509 & Wheat straw & DA & batch & & DLH & 21 & 16 & 27 & 4.2 & & [201] \\
\hline Lipomyces starkeyi & ATCC 12659 & Wheat straw & DA & batch & & ULH & 29 & 15 & 31 & 4.6 & & [201] \\
\hline Lipomyces starkeyi & ATCC 12659 & Wheat straw & DA & batch & & DLH & 21 & 13 & 29 & 3.7 & & [201] \\
\hline Rhodosporidium toruloides & ATCC 10788 & Wheat straw & DA & batch & & DLH & 21 & 9.9 & 25 & 2.4 & & [201] \\
\hline Rhodotorula glutinis & ATCC 204091 & Wheat straw & DA & batch & & ULH & 29 & 14 & 25 & 3.5 & & [201] \\
\hline Rhodotorula glutinis & ATCC 204091 & Wheat straw & DA & batch & & DLH & 21 & 12 & 21 & 2.4 & & [201] \\
\hline Trichosporon dematis & 32903 & Corncob & DA & batch & & ULH & 71 & & 24 & 7.5 & 0.1 & [73] \\
\hline Trichosporon dematis & 32903 & Corncob & DA & batch & & DLH & 73 & & 45 & 11 & 0.16 & [73] \\
\hline Cryptococcus sp. & SM5S05 & Corncob & DA & batch & flask & ULH & 40 & 13 & 60 & 7.6 & 0.13 & [259] \\
\hline Trichosporon cutaneum & Ch002 & Corncob & DA & batch & flask & DLH & 46 & 22 & 36 & 7.9 & & [260] \\
\hline Trichosporon cutaneum & ACCC 20271 & Corncob & DA & batch & flask & ULH & 49 & 38 & 32 & 12 & 0.1 & [261] \\
\hline Cryptococcus curvatus & ATCC 20509 & Corn stover & DA & batch & flask & ULH & 53 & 11 & 61 & 6.9 & & [262] \\
\hline Trichosporon cutaneum & AS 2.571 & Corn stover & DA & batch & Bior 3L & DLH & 60 & 19 & 39 & 7.6 & 0.15 & [110] \\
\hline Trichosporon dematis & $\mathrm{CH} 007$ & Corncob & DA & batch & flask & ULH & 60 & 24 & 40 & 9.8 & 0.16 & [263] \\
\hline Trichosporon fermentans & CICC 1368 & Rice straw & DA & batch & flask & DLH & 35 & 29 & 40 & 12 & & [228] \\
\hline Lipomyces tetrasporus & $\begin{array}{c}\text { NRRL } \\
\text { Y-11562 }\end{array}$ & Cornstover & DA & batch & flask & ULH & 123 & 54 & 53 & 29 & 0.15 & [40] \\
\hline Lipomyces kononenkoae & NRRL Y-7042 & Cornstover & DA & batch & flask & ULH & 123 & 48 & 59 & 28 & 0.22 & [40] \\
\hline Rhodosporidium toruloides & NRRL Y-1091 & Cornstover & DA & batch & flask & ULH & 123 & 43 & 61 & 26 & 0.19 & [40] \\
\hline Yarrowia lipolytica & Po1g & Sugarcane bagasse & DA & batch & flask & DLH & 21 & 11 & 59 & 6.7 & & [118] \\
\hline Yarrowia lipolytica & Polg & Rice bran & DA & batch & flask & DLH & 30 & 11 & 48 & 5.2 & & [56] \\
\hline Trichosporon cutaneum & ACCC 20271 & Corn stover & DA & batch & Bior 20L & DLH & $73-130$ & & 46 & 8.1 & & [146] \\
\hline Rhodosporidiobolus fluvialis & DMKU-SP314 & Sugar cane & $\mathrm{DA} / \mathrm{OX}$ & batch & flask & ULH & 36 & 21 & 67 & 14 & & [113] \\
\hline Rhodosporidiobolus fluvialis & DMKU-SP314 & Sugar cane & $\mathrm{DA} / \mathrm{OX}$ & batch & Bior 2L & ULH & 36 & 24 & 75 & 18 & & [113] \\
\hline Trichosporon mycotoxinivorans & S 2 & Paddy straw & Alk & & & ULH & 35 & 14 & 35 & 7.3 & & [50] \\
\hline Rhodosporidium paludigenum & KM281510 & Corncob & Alk & batch & flask & ULH & 100 & 23 & 70 & 16 & & [47] \\
\hline Rhodosporidium paludigenum & KM281510 & Corncob & Alk & batch & Bior 3L & ULH & 100 & 28 & 70 & 20 & 0.21 & [47] \\
\hline Rhodosporidium paludigenum & KM281510 & Corncob & Alk & fed batch & Bior 3L & ULH & 100 & 36 & 70 & 25 & 0.28 & [47] \\
\hline Trichosporon dematis & 32903 & Corncob & Alk & batch & & ULH & 67 & & 28 & 6.8 & 0.1 & [73] \\
\hline Trichosporon dematis & 32903 & Corncob & Alk & batch & & DLH & 131 & & 56 & 20 & 0.19 & [73] \\
\hline Rhodosporidium toruloides & DSMZ 4444 & Corn stover & $\mathrm{A} / \mathrm{A}$ & batch & & ULH & 110 & 36 & 59 & & 0.19 & [264] \\
\hline Rhodosporidium toruloides & DSMZ 4445 & Corn stover & $\mathrm{A} / \mathrm{A}$ & Fed batch & & ULH & 110 & 54 & 59 & & 0.29 & [264] \\
\hline
\end{tabular}


Table 4. Cont.

\begin{tabular}{|c|c|c|c|c|c|c|c|c|c|c|c|c|}
\hline Microorganism & Strain & Biomass & Pretreatment & Sy & & ULH/DLH & $S(g / L)$ & $\mathrm{X}(\mathrm{g} / \mathrm{L})$ & $\mathrm{L} \%(w / w)$ & $\mathrm{L}(\mathrm{g} / \mathrm{L})$ & $L(g / g)$ & Reference \\
\hline \multicolumn{13}{|l|}{ Yeasts } \\
\hline Rhodotorula glutinis & CGMCC 2.703 & Corncob & $\mathrm{A} / \mathrm{A}$ & batch & Bior 5L & ULH & 42 & 15 & 36 & 5.5 & 0.13 & [265] \\
\hline Rhodotorula glutinis & CGMCC 2.703 & Corncob & $\mathrm{A} / \mathrm{A}$ & fed batch & Bior 5L & ULH & 42 & 75 & 47 & 34 & 0.15 & [265] \\
\hline Meyerozyma guilliermondii & G5-MK414782 & Sugarcane bagasse & SE & batch & & ULH & 60 & 6.1 & 38 & 2.3 & 0.05 & [48] \\
\hline Meyerozyma guilliermondii & G5-MK414782 & Rice husk & SE & batch & & ULH & 60 & 6.5 & 37 & 2.4 & 0.04 & [48] \\
\hline Pichia kudriavzevii & G9-MH000699 & Sugarcane bagasse & SE & batch & & ULH & 20 & 6.2 & 31 & 1.9 & 0.1 & [48] \\
\hline Pichia kudriavzevii & G9-MH000699 & Rice husk & SE & batch & & ULH & 20 & 8.2 & 24 & 1.9 & 0.1 & [48] \\
\hline Pichia manshurica & G10-MH279643 & Sugarcane bagasse & SE & batch & & ULH & 20 & 8.2 & 24 & 1.9 & 0.09 & [48] \\
\hline Pichia manshurica & G10-MH279643 & Rice husk & SE & batch & & ULH & 21 & 6.5 & 28 & 1.8 & 0.09 & [48] \\
\hline Pichia kudriavzevii & SY2-MF926445 & Sugarcane bagasse & SE & batch & & ULH & 60 & 6.1 & 30 & 1.9 & 0.04 & [48] \\
\hline Pichia kudriavzevii & SY2-MF926445 & Rice husk & SE & batch & & ULH & 51 & 8.4 & 29 & 2.4 & 0.04 & [48] \\
\hline Candida albicans & SY3-MG996750 & Sugarcane bagasse & SE & batch & & ULH & 20 & 6.2 & 31 & 1.9 & 0.1 & [48] \\
\hline Candida albicans & SY3-MG996750 & Rice husk & $\mathrm{SE}$ & batch & & ULH & 21 & 8.3 & 22 & 1.8 & 0.09 & [48] \\
\hline Rhodotorula mucilaginosa & SY4-MH279637 & Sugarcane bagasse & SE & batch & & ULH & 20 & 6.7 & 30 & 2 & 0.1 & [48] \\
\hline Rhodotorula mucilaginosa & SY4-MH279637 & Rice husk & SE & batch & & ULH & 20 & 8 & 24 & 2 & 0.1 & [48] \\
\hline \multicolumn{13}{|l|}{ Filamentous fungi } \\
\hline $\begin{array}{l}\text { Umbelopsis (Mortierella) } \\
\text { isabellina }\end{array}$ & ATHUM 2935 & Rice hull & DA & batch & flask & ULH & 26 & 5.6 & 64 & 3.6 & 0.21 & [69] \\
\hline $\begin{array}{l}\text { Umbelopsis (Mortierella) } \\
\text { isabellina }\end{array}$ & ATCC42613 & Corn stover & DA & batch & flask & $\mathrm{ULH}$ & 31 & 14 & 34 & 4.8 & & {$[38]$} \\
\hline $\begin{array}{l}\text { Umbelopsis (Mortierella) } \\
\text { isabellina }\end{array}$ & ATCC42613 & Corn stover & Alk & batch & flask & $\mathrm{ULH}$ & 30 & 11 & 29 & 2.5 & & {$[38]$} \\
\hline \multicolumn{13}{|l|}{ Microalgae } \\
\hline $\begin{array}{c}\text { Auxenochlorella (Chlorella) } \\
\text { protothecoides }\end{array}$ & & Birch & OS/SE & batch & flask & ULH & 77 & 8.6 & 66 & 5.7 & & [257] \\
\hline $\begin{array}{c}\text { Auxenochlorella (Chlorella) } \\
\text { protothecoides }\end{array}$ & & Spruce & $\mathrm{OS} / \mathrm{SE}$ & batch & flask & ULH & 65 & 8.6 & 63 & 5.3 & & [257] \\
\hline \multicolumn{13}{|l|}{ Bacteria } \\
\hline Rhodococcus opacus & DSM 1069 & Loblolly pine & OS & batch & flask & & & & 27 & & & [266] \\
\hline
\end{tabular}

Abbreviations: DA, dilute acid; Alk, alkaline; A/A, acid/alkaline; SE, steam explosion; OX, oxidative; OS, organosolv; S, substrate; X, biomass; L, lipids; ULH, undetoxified lignocellulosic hydrolysates; DLH, detoxified lignocellulosic hydrolysates; Bior, bioreactor. 


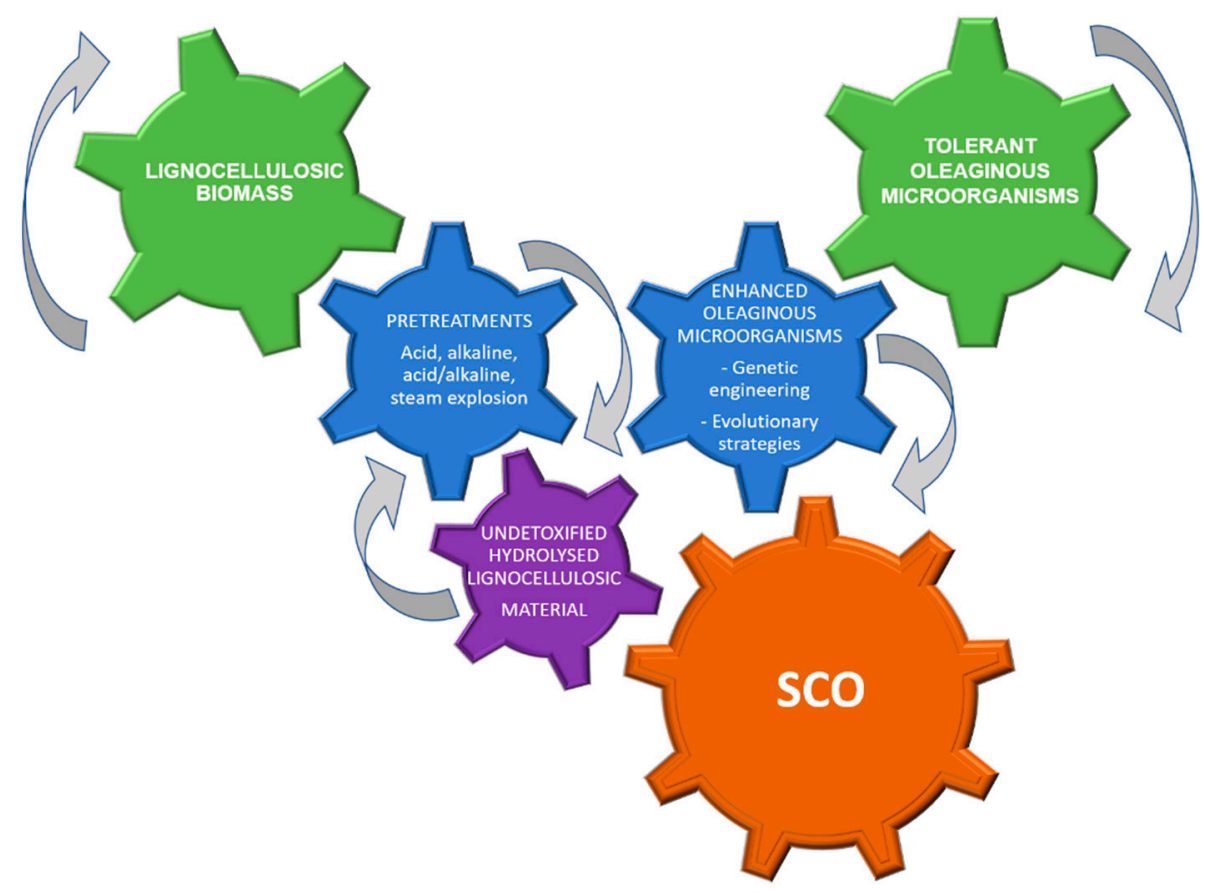

Figure 4. A conceptual scheme of lignocellulosic hydrolysates conversion into SCO (Single Cell Oil).

The application of surfactants in ULH has a positive effect on microbial growth and lipid production [267]. Some anionic surfactants were effective at promoting the production of the oleaginous yeast $R$. toruloides, with the most significant impact achieved with the addition of $0.2 \%$ $(w / v)$ sodium lignosulfonate [267]. The non-ionic surfactant polyoxyethylene sorbitan monooleate (Tween-80), added at a rate $1 \%(w / v)$ in the hydrolysate, has also been reported to increase cell mass production and lipid content of the marine protist Thraustochytrium aureum ATCC 34304 [268]. However, Tween-80 used in $R$. toruloides growing in hydrolysate does not have a positive effect. Surfactants apparently denature the cell wall proteins and structure, altering their permeability. However, the exact mechanism requires further investigation in oleaginous microorganisms in order to enhance their growth and lipid accumulation in hydrolyzed lignocellulosic media $[267,268]$.

The reduction of hydrolyzed lignocellulosic biomass toxicity can be achieved by removing inhibitory compounds using different techniques, such as chemical additives, enzymatic treatments, heating and vaporization, liquid-liquid extraction, liquid-solid extraction and microbial treatment [239]. Particularly, the detoxification through the addition of $\mathrm{Ca}(\mathrm{OH})_{2}$ is commonly used, as a neutralization of the pretreated lignocellulosic biomass using this agent significantly reduces the concentration of 5-HMF, furfural and phenolic compounds by approximately 20-30\% [118,269]. Additionally, resin adsorption and electrodialysis or as recently reported biological detoxification by bacteria, such as Bordetella sp. And Bacillus sp., have been considered as efficient strategies to remove HMF and furfural [270-273]. However, the additional treatment needed for detoxification increases the production cost and results in a loss of assimilable sugars [271].

Detoxification of pretreated lignocellulosic biomass does not seem to be a very attractive approach, as the techniques used result in sugar loss, and also imply an increase in costs due to the addition of more stages in the process [19]. On the contrary, the use of ULH can be a good alternative with lower processing costs, provided that tolerant oleaginous microorganisms, such as strains of Trichosporon, Cryptococcus, Lipomyces, Rhodotorula, Umbelopsis (Mortierella), Rhodosporidiobolus, Rhodosporidium, Rhodococcus, Meyerozyma, Pichia and Candida will be used (Table 4).

ULH obtained from agricultural residues pretreated with weak acids seems to be suitable as a substrate for SCO production by the aforementioned oleaginous microorganisms, supporting lipid accumulation at high rates, even above $60 \% w / w$ (Table 4 ). Likewise, some oleaginous yeasts also 
accumulate high lipid amounts growing on ULH derived from combined (e.g., acid and other) pretreatments. For example, Poontawee et al. [113] showed that the yeast Rhodosporidiobolus fluvialis was able to produce up to $75 \% w / w$ of lipids growing on hydrolyzed sugarcane biomass obtained after acid/oxidative pretreatment. The alkaline pretreatment is also an important possibility dealing to high lipids productivities. Chaiyaso et al. [47] have shown an efficient bioconversion of ULH derived from alkaline pretreatment of corncob into Rhodosporidium paludigenum oily biomass containing approximately $70 \% w / w$ lipid. On the other hand, agricultural residues pretreated using steam explosion are also an interesting option. For instance, significant lipid accumulation (ranging from $22 \%$ to $38 \%$ $w / w)$ was observed by Ananthi et al. [48] in different conventional oleaginous microorganisms growing on ULH agricultural biomass pretreated with steam explosion.

The physiological response of oleaginous microorganisms to inhibitors generated during pretreatment of lignocellulosic biomass has been studied in various microorganisms including Candida, Rhodosporidium, Cryptococcus, Trichosporon, Rhodococcus, Wickerhamomyces and Vanrija, and interesting results have been obtained regarding tolerance and even degradation of inhibitors $[36,41,73,104,113$, 146,240,262]. For example, T. cutaneum can convert $3 \mathrm{~g} / \mathrm{L}$ of furfural and $3 \mathrm{~g} / \mathrm{L}$ of HMF into the corresponding alcohols (furfuryl alcohol and HMF alcohol) and completely degrade $15 \mathrm{~g} / \mathrm{L}$ of formic acid and $10 \mathrm{~g} / \mathrm{L}$ of acetic acid [146]. In addition, enzymes involved in the degradation of furfural and $\mathrm{HMF}$, including alcohol dehydrogenase, aldehyde reductase and aldehyde dehydrogenase, have been identified in yeasts strains such as T. cutaneum ACCC 20271, R. toruloides NP11, Y. lipolytica CLIB122 and T. oleaginosus IBC0246. The number of putative functional genes in the genomes involved in the synthesis of the aforementioned enzymes is higher in T. cutaneum ACCC 20271, providing a strong support for high degradation capacity and tolerance to inhibitors [147]. However, more metabolic studies are required to understand the physiology of oleaginous microorganisms against lignocellulose biomass derived inhibitors.

Tolerance to inhibitors is a required, but not a sufficient, property for selecting an oleaginous microorganism to be used in lignocellulosic hydrolysates conversion to SCO; effective growth and lipogenicity are also needed for a sustainable process. As shown in Table 3, naturally tolerant microorganisms usually have a restricted capacity to effectively convert sugars into lipid-rich biomass. To overcome these difficulties, recombinant microorganisms could be constructed, simultaneously presenting tolerance, efficient growth and lipogenicity. Genetically modified strains of Saccharomyces cerevisiae, yeast widely used in the conversion of lignocellulosic substrates to ethanol, showing increased tolerance to inhibitors, such as furfural and HMF, have been constructed, and this knowledge could be used for constructing new oleaginous strains. For example, S. cerevisiae strains ADH6p and ADH7 overexpressing alcohol dehydrogenase exhibit strong furfural and HMF reducing activities, and in some cases improve growth performance in the presence of aldehyde [232]. On the other hand, the experience of genetic manipulations in the oleaginous yeast $Y$. lipolytica can be used in this context [274]. Both streams of research pave the way for the genetic transformation of oleaginous yeasts, such as the yeast Candida phangngensis, the modified strain JQCP04 of which, overexpressed the alcohol dehydrogenase gene of S. cerevisiae (ADH6p) under strong control of the TEF constitutive promoter of Y. lipolytica [275]. This overexpression allows the reduction of the aldehyde group of the furfural inhibitor to an alcohol, greatly decreasing toxicity, reducing the lag time by $58 \%$ and increasing the growth rate compared to wild-type C. phangngensis. In a similar study, ADH6 was overexpressed in Y. lipolytica YB-392 [276]. The modified strain, although it presented a furfural reduction capacity, did not present significant difference in terms of lag time, specific growth rate or biomass yield in the presence of $10 \mathrm{mM}$ furfural, when compared to the wild type.

Some oleaginous red yeasts of the Division Basidiomycota, such as Rhodotorula mucilaginosa BIS11 and Rhodotorula (Rhodosporidium) toruloides BIS18, are known to convert hexoses, pentoses, organic acids and aromatic monomers into cell mass rich in lipids, carotenoids, terpenes and precursors of various bioproducts, such as bisabolene $[277,278]$. The aforementioned yeasts have been genetically 
modified, and the derived strains present an enhanced ability to synthesize bioactive compounds, such as bisabolene, when grown on different ULH [109].

Finally, alternatively or in addition to genetic engineering, directed evolution strategies can be developed in order to enhance lipid accumulation inoleaginous microorganisms. An adaptive evolution strategy of Yarrowia lipolytica growing in alternative environments that promote growth and encourage the synthesis of storage lipids, followed by conditions that reward the high-energy containing cells, has been developed. The oleaginous lineages obtained give rise to populations capable of accumulating $30 \% w / w$ more lipids than the initial strain. Similar strategies could be used as a robust tool to generate tolerant strains able to grow on ULH and accumulate high amounts of lipids [20]. Regardless of the approach used for improving productivity of oleaginous microorganisms, the environmental and economic viability of SCOs can be improved by adopting biorefinery approaches, as the exploitation and commercialization of the various by-products of the SCO production process, such as proteins, amino acids, carbohydrates, carotenoids, glycerol, organic acids, and alcohols [50,135,232,279-281] may be critical in determining the minimum selling price of microbial oil.

\section{Outlook}

The conversion of lignocellulosic biomass into SCO could be a promising technology, considering the new strategies related to the pretreatment of lignocellulosic biomass, as well as to the improvement of the productivity of oleaginous microorganisms through genetic engineering in combination with adaptive laboratory evolution. Chemical pretreatments, such as acid, alkaline and acid/alkaline, have proven to be promising technologies for obtaining high yields of assimilable sugars after enzymatic hydrolysis. Steam explosion is considered to be an effective, although energy consuming, strategy. Specifically, the acid treatments, especially those using diluted acids at a temperature of $121{ }^{\circ} \mathrm{C}$ or higher, are the most popular, allowing a high recovery of pentoses and hexoses after enzymatic hydrolysis. Concerning the inhibition of the oleaginous microorganisms caused by the inhibitory compounds generated during pretreatments, future efforts should concentrate on the optimization of the pretreatment process, so as to reduce by-products and improve sugar yield, as well as to the identification of tolerant to inhibitors microorganisms and capable of efficiently consuming lignocellulosic sugars. The application of genetic engineering and/or adaptive evolutionary techniques would greatly reduce limitations in lignocellulosic biomass valorization.

Technological advances in the conversion of lignocellulosic biomass into SCOs can promote sustainable production of SCOs to meet the needs of the population through the production of products such as food, biofuels and fine chemicals.

Author Contributions: Conceptualization, G.V., R.T.M. and G.A.; writing-original draft preparation, G.V.; writing-review and editing, R.T.M. and G.A.; supervision, G.A.; project administration, G.V.; funding acquisition, G.V. All authors have read and agreed to the published version of the manuscript.

Funding: The project was financially supported by the CONICYT PFCHA/DOCTORADO BECAS CHILE/2018-21180068, UNIVERSIDAD DE CONCEPCIÓN POSTGRATE PROGRAM CHILE 2019 and CONICYT (ANID) I+D Ciencia y territorio 2019. N R19F10005.

Conflicts of Interest: The authors declare that they have no known competing financial interests or personal relationships that could have appeared to influence the work reported in this paper.

\section{References}

1. Ratledge, C.; Wynn, J.P. The biochemistry and molecular biology of lipid accumulation in oleaginous microorganisms. Adv. Appl. Microbiol. 2002, 51, 1-51. [CrossRef] [PubMed]

2. Fakas, S.; Papanikolaou, S.; Batsos, A.; Galiotou-Panayotou, M.; Mallouchos, A.; Aggelis, G. Evaluating renewable carbon sources as substrates for single cell oil production by Cunninghamella echinulata and Mortierella isabellina. Biomass Bioenergy 2009, 33, 573-580. [CrossRef]

3. Bellou, S.; Baeshen, M.N.; Elazzazy, A.M.; Aggeli, D.; Sayegh, F.; Aggelis, G. Microalgal lipids biochemistry and biotechnological perspectives. Biotechnol. Adv. 2014, 32, 1476-1493. [CrossRef] [PubMed] 
4. Bellou, S.; Triantaphyllidou, I.E.; Aggeli, D.; Elazzazy, A.M.; Baeshen, M.N.; Aggelis, G. Microbial oils as food additives: Recent approaches for improving microbial oil production and its polyunsaturated fatty acid content. Curr. Opin. Biotechnol. 2016, 37, 24-35. [CrossRef]

5. Bellou, S.; Triantaphyllidou, I.E.; Mizerakis, P.; Aggelis, G. High lipid accumulation in Yarrowia lipolytica cultivated under double limitation of nitrogen and magnesium. J. Biotechnol. 2016, 234, 116-126. [CrossRef]

6. Dourou, M.; Aggeli, D.; Papanikolaou, S.; Aggelis, G. Critical steps in carbon metabolism affecting lipid accumulation and their regulation in oleaginous microorganisms. Appl. Microbiol. Biotechnol. 2018, 102, 2509-2523. [CrossRef]

7. Kothri, M.; Mavrommati, M.; Elazzazy, A.M.; Baeshen, M.N.; Moussa, T.A.A.; Aggelis, G. Microbial sources of polyunsaturated fatty acids (PUFAs) and the prospect of organic residues and wastes as growth media for PUFA-producing microorganisms. FEMS. Microbiol. Lett. 2020, 367. [CrossRef]

8. Sreeharsha, R.V.; Mohan, S.V. Obscure yet promising oleaginous yeasts for fuel and chemical production. Trends Biotechnol. 2020, 38, 873-887. [CrossRef]

9. Adrio, J.L. Oleaginous yeasts: Promising platforms for the production of oleochemicals and biofuels. Biotechnol. Bioeng. 2017, 114, 1915-1920. [CrossRef]

10. Singh, J.; Gu, S. Commercialization potential of microalgae for biofuels production. Renew. Sustain. Energy Rev. 2010, 14, 2596-2610. [CrossRef]

11. Li, X.; Xu, H.; Wu, Q. Large-scale biodiesel production from microalga Chlorella protothecoides through heterotrophic cultivation in bioreactors. Biotechnol. Bioeng. 2007, 98, 764-771. [CrossRef] [PubMed]

12. Reyes, P.; Mendonça, R.T.; Aguayo, M.G.; Rodríguez, J.; Vega, B.; Fardim, P. Extraction and characterization of hemicelluloses from Pinus radiata and its feasibility for bioethanol production. Rev. Arvore. 2013, 37, 175-180. [CrossRef]

13. Bhutto, A.W.; Qureshi, K.; Harijan, K.; Abro, R.; Abbas, T.; Bazmi, A.A.; Karim, S.; Yu, G. Insight into progress in pre-treatment of lignocellulosic biomass. Energy 2017, 122, 724-745. [CrossRef]

14. Abo, B.O.; Gao, M.; Wang, Y.; Wu, C.; Ma, H.; Wang, Q. Lignocellulosic biomass for bioethanol: An overview on pretreatment, hydrolysis and fermentation processes. Rev. Environ. Health 2019, 34, 57-68. [CrossRef]

15. Jönsson, L.J.; Martín, C. Pretreatment of lignocellulose: Formation of inhibitory by-products and strategies for minimizing their effects. Bioresour. Technol. 2016, 199, 103-112. [CrossRef] [PubMed]

16. He, Y.; Zhang, J.; Bao, J. Acceleration of biodetoxification on dilute acid pretreated lignocellulose feedstock by aeration and the consequent ethanol fermentation evaluation. Biotechnol. Biofuels 2016, 9, 1-13. [CrossRef] [PubMed]

17. Park, Y.K.; Nicaud, J.M.; Ledesma-Amaro, R. The engineering potential of Rhodosporidium toruloides as a workhorse for biotechnological applications. Trends Biotechnol. 2018, 36, 304-317. [CrossRef] [PubMed]

18. Tsai, Y.Y.; Ohashi, T.; Wu, C.C.; Bataa, D.; Misaki, R.; Limtong, S.; Fujiyama, K. Delta-9 fatty acid desaturase overexpression enhanced lipid production and oleic acid content in Rhodosporidium toruloides for preferable yeast lipid production. J. Biosci. Bioeng. 2019, 127, 430-440. [CrossRef]

19. Singh, P.; Kumari, S.; Guldhe, A.; Misra, R.; Rawat, I.; Bux, F. Trends and novel strategies for enhancing lipid accumulation and quality in microalgae. Renew. Sustain. Energy Rev. 2016, 55, 1109-1128. [CrossRef]

20. Daskalaki, A.; Perdikouli, N.; Aggeli, D.; Aggelis, G. Laboratory evolution strategies for improving lipid accumulation in Yarrowia lipolytica. Appl. Microbiol. Biotechnol. 2019, 103, 8585-8596. [CrossRef]

21. Liu, Y.; Zuo, S.; Xu, L.; Zou, Y.; Song, W. Study on diversity of endophytic bacterial communities in seeds of hybrid maize and their parental lines. Arch. Microbiol. 2012, 194, 1001-1012. [CrossRef] [PubMed]

22. Anwar, Z.; Gulfraz, M.; Irshad, M. Agro-industrial lignocellulosic biomass a key to unlock the future bio-energy: A brief review. J. Radiat. Res. Appl. Sci. 2014, 7, 163-173. [CrossRef]

23. Tsolcha, O.N.; Tekerlekopoulou, A.G.; Akratos, C.S.; Aggelis, G.; Genitsaris, S.; Moustaka-Gouni, M.; Vayenas, D.V. Biotreatment of raisin and winery wastewaters and simultaneous biodiesel production using a Leptolyngbya-based microbial consortium. J. Clean. Prod. 2017, 148, 185-193. [CrossRef]

24. Bhatia, S.K.; Yi, D.; Kim, Y.; Kim, H.; Seo, H.; Lee, J.; Kim, J.; Jeon, J.; Jang, K.; Kim, Y.; et al. Development of semi-synthetic microbial consortia of Streptomyces coelicolor for increased production of biodiesel (fatty acid methyl esters). Fuel 2015, 159, 189-196. [CrossRef]

25. Zhang, C.; Liu, P. The new face of the lipid droplet: Lipid droplet proteins. Proteomics 2019, 19, 1700223. [CrossRef] 
26. Papanikolaou, S.; Aggelis, G. Lipids of oleaginous yeasts. Part I: Biochemistry of single cell oil production. Eur. J. Lipid Sci. Technol. 2011, 113, 1031-1051. [CrossRef]

27. Bellou, S.; Aggelis, G. Biochemical activities in Chlorella sp. and Nannochloropsis salina during lipid and sugar synthesis in a lab-scale open pond simulating reactor. J. Biotechnol. 2013, 164, 318-329. [CrossRef]

28. Vanthoor-Koopmans, M.; Wijffels, R.H.; Barbosa, M.J.; Eppink, M.H.M. Biorefinery of microalgae for food and fuel. Bioresour. Technol. 2013, 135, 142-149. [CrossRef]

29. De Olivera-Finco, A.M.; Goyzueta-Mamani, L.D.; de Carvalho, J.C.; de Melo Pereira, G.V.; Thomaz-Soccol, V.; Soccol, C.R. Technological trends and market perspectives for production of microbial oils rich in omega-3. Crit. Rev. Biotechnol. 2017, 37, 656-671. [CrossRef]

30. Dourou, M.; Tsolcha, O.N.; Tekerlekopoulou, A.; Bokas, D.; Aggelis, G. Fish farm effluents are suitable growth media for Nannochloropsis gaditana, a polyunsaturated fatty acid producing microalga. Eng. Life Sci. 2018, 18, 851-860. [CrossRef]

31. Malibari, R.; Sayegh, F.; Elazzazy, A.M.; Baeshen, M.N.; Dourou, M.; Aggelis, G. Reuse of shrimp farm wastewater as growth medium for marine microalgae isolated from Red Sea-Jeddah. J. Clean. Prod. 2018, 198, 160-169. [CrossRef]

32. Deshmukh, S.; Kumar, R.; Bala, K. Microalgae biodiesel: A review on oil extraction, fatty acid composition, properties and effect on engine performance and emissions. Fuel Process. Technol. 2019, 191, $232-247$. [CrossRef]

33. Patel, A.; Karageorgou, D.; Rova, E.; Katapodis, P.; Rova, U.; Christakopoulos, P.; Matsakas, L. An overview of potential oleaginous microorganisms and their role in biodiesel and omega-3 fatty acid-based industries. Microorganisms 2020, 8, 434. [CrossRef]

34. Alvarez, H.M.; Steinbüchel, A. Triacylglycerols in prokaryotic microorganisms. Appl. Microbiol. Biotechnol. 2002, 60, 367-376. [CrossRef] [PubMed]

35. Kosa, M.; Ragauskas, A.J. Bioconversion of lignin model compounds with oleaginous Rhodococci. Appl. Microbiol. Biotechnol. 2012, 93, 891-900. [CrossRef] [PubMed]

36. Kosa, M.; Ragauskas, A.J. Lignin to lipid bioconversion by oleaginous Rhodococci. Green Chem. 2013, 15, 2070-2074. [CrossRef]

37. Gouda, M.K.; Omar, S.H.; Aouad, L.M. Single cell oil production by Gordonia sp. DG using agro-industrial wastes. World J. Microbiol. Biotechnol. 2008, 24, 1703-1711. [CrossRef]

38. Ruan, Z.; Zanotti, M.; Wang, X.; Ducey, C.; Liu, Y. Evaluation of lipid accumulation from lignocellulosic sugars by Mortierella isabellina for biodiesel production. Bioresour. Technol. 2012, 110, 198-205. [CrossRef]

39. Sitepu, I.; Selby, T.; Lin, T.; Zhu, S.; Boundy-Mills, K. Carbon source utilization and inhibitor tolerance of 45 oleaginous yeast species. J. Ind. Microbiol. Biothecnol. 2014, 41, 1061-1070. [CrossRef]

40. Slininger, P.J.; Dien, B.S.; Kurtzman, C.P.; Moser, B.R.; Bakota, E.L.; Thompson, S.R.; O’Bryan, P.J.; Cotta, M.A.; Balan, V.; Jin, M.; et al. Comparative lipid production by oleaginous yeasts in hydrolyzates of lignocellulosic biomass and process strategy for high titers. Biotechnol. Bioeng. 2016, 113, 1676-1690. [CrossRef]

41. Gong, Z.; Shen, H.; Zhou, W.; Wang, Y.; Yang, X.; Zhao, Z.K. Efficient conversion of acetate into lipids by the oleaginous yeast Cryptococcus curvatus. Biotechnol. Biofuels 2015, 8, 1-9. [CrossRef]

42. Arous, F.; Frikha, F.; Triantaphyllidou, I.E.; Aggelis, G.; Nasri, M.; Mechichi, T. Potential utilization of agro-industrial wastewaters for lipid production by the oleaginous yeast Debaryomyces etchellsii. J. Clean. Prod. 2016, 133, 899-909. [CrossRef]

43. Gardeli, C.; Athenaki, M.; Xenopoulos, E.; Mallouchos, A.; Koutinas, A.A.; Aggelis, G.; Papanikolaou, S. Lipid production and characterization by Mortierella (Umbelopsis) isabellina cultivated on lignocellulosic sugars. J. Appl. Microbiol. 2017, 123, 1461-1477. [CrossRef] [PubMed]

44. Dourou, M.; Mizerakis, P.; Papanikolaou, S.; Aggelis, G. Storage lipid and polysaccharide metabolism in Yarrowia lipolytica and Umbelopsis isabellina. Appl. Microbiol. Biotechnol. 2017, 101, 7213-7226. [CrossRef] [PubMed]

45. Cho, H.U.; Park, J.M. Biodiesel production by various oleaginous microorganisms from organic wastes. Bioresour. Technol. 2018, 256, 502-508. [CrossRef]

46. Papanikolaou, S.; Aggelis, G. Sources of microbial oils with emphasis to Mortierella (Umbelopsis) isabellina fungus. World J. Microbiol. Biotechnol. 2019, 35, 63. [CrossRef] 
47. Chaiyaso, T.; Manowattana, A.; Techapun, C.; Watanabe, M. Efficient bioconversion of enzymatic corncob hydrolysate into biomass and lipids by oleaginous yeast Rhodosporidium paludigenum KM281510. Prep. Biochem. Biotechnol. 2019, 49, 545-556. [CrossRef] [PubMed]

48. Ananthi, V.; Siva Prakash, G.; Chang, S.W.; Ravindran, B.; Nguyen, D.D.; Vo, D.V.N.; La, D.D.; Bach, Q.V.; Wong, J.W.C.; Gupta, S.; et al. Enhanced microbial biodiesel production from lignocellulosic hydrolysates using yeast isolates. Fuel 2019, 256, 115932. [CrossRef]

49. Llamas, M.; Dourou, M.; González-Fernández, C.; Aggelis, G.; Tomás-Pejó, E. Screening of oleaginous yeasts for lipid production using volatile fatty acids as substrate. Biomass Bioenergy 2020, 138, 105553. [CrossRef]

50. Sagia, S.; Sharma, A.; Singh, S.; Chaturvedi, S.; Singh-Nain, P.K.; Nain, L. Single cell oil production by a novel yeast Trichosporon mycotoxinivorans for complete and ecofriendly valorization of paddy straw. Electron. J. Biotechnol. 2020, 44, 60-68. [CrossRef]

51. Papanikolaou, S.; Galiotou-Panayotou, M.; Fakas, S.; Komaitis, M.; Aggelis, G. Lipid production by oleaginous Mucorales cultivated on renewable carbon sources. Eur. J. Lipid Sci. Technol. 2007, 109, 1060-1070. [CrossRef]

52. Makri, A.; Fakas, S.; Aggelis, G. Metabolic activities of biotechnological interest in Yarrowia lipolytica grown on glycerol in repeated batch cultures. Bioresour. Technol. 2010, 101, 2351-2358. [CrossRef] [PubMed]

53. Economou, C.N.; Makri, A.; Aggelis, G.; Pavlou, S.; Vayenas, D.V. Semi-solid state fermentation of sweet sorghum for the biotechnological production of single cell oil. Bioresour. Technol. 2010, 101, 1385-1388. [CrossRef]

54. Economou, C.N.; Vasiliadou, I.A.; Aggelis, G.; Pavlou, S.; Vayenas, D.V. Modeling of oleaginous fungal biofilm developed on semi-solid media. Bioresour. Technol. 2011, 102, 9697-9704. [CrossRef] [PubMed]

55. Chatzifragkou, A.; Makri, A.; Belka, A.; Bellou, S.; Mavrou, M.; Mastoridou, M.; Mystrioti, P.; Onjaro, G.; Aggelis, G.; Papanikolaou, S. Biotechnological conversions of biodiesel derived waste glycerol by yeast and fungal species. Energy 2011, 36, 1097-1108. [CrossRef]

56. Tsigie, Y.A.; Wang, C.; Kasim, N.S.; Diem, Q.; Huynh, L.; Ho, Q.; Truong, C.; Ju, Y. Oil Production from Yarrowia lipolytica Po1g using rice bran hydrolysate. J. Biomed. Biotechnol. 2012, 378384. [CrossRef]

57. Beopoulos, A.; Nicaud, J.M. Yeast: A new oil producer? Oléagineux Corps Gras Lipides 2012, 19, $22-28$. [CrossRef]

58. Kazamia, E.; Czesnick, H.; Van Nguyen, T.T.; Croft, M.T.; Sherwood, E.; Sasso, S.; Hodson, S.J.; Warren, M.J.; Smith, A.G. Mutualistic interactions between vitamin B 12 -dependent algae and heterotrophic bacteria. Environ. Microbiol. 2012, 14, 1466-1476. [CrossRef]

59. Xie, B.; Bishop, S.; Stessman, D.; Wright, D.; Spalding, M.H.; Halverson, L.J. Chlamydomonas reinhardtii thermal tolerance enhancement mediated by a mutualistic interaction with vitamin B 12-producing bacteria. ISME J. 2013, 7, 1544-1555. [CrossRef]

60. Gonçalves, A.L.; Pires, J.C.M.; Simões, M. Biotechnological potential of Synechocystis salina co-cultures with selected microalgae and cyanobacteria: Nutrients removal, biomass and lipid production. Bioresour. Technol. 2016, 200, 279-286. [CrossRef]

61. Cho, H.U.; Kim, Y.; Park, J.M. Enhanced microalgal biomass and lipid production from a consortium of indigenous microalgae and bacteria present in municipal wastewater under gradually mixotrophic culture conditions. Bioresour. Technol. 2017, 228, 290-297. [CrossRef] [PubMed]

62. Shu, C.; Tsai, C.; Chen, K.; Liao, W.; Huang, H. Enhancing high quality oil accumulation and carbon dioxide fixation by a mixed culture of Chlorella $s p$ and Saccharomyces cerevisiae. J. Taiwan Inst. Chem. Eng. 2013, 44, 936-942. [CrossRef]

63. Kitcha, S.; Cheirsilp, B. Enhanced lipid production by co-cultivation and co-encapsulation of oleaginous yeast Trichosporonoides spathulata with microalgae in alginate gel beads. Appl. Biochem. Biotechnol. 2014, 173, 522-534. [CrossRef]

64. Ling, J.; Nip, S.; Cheok, W.L.; de Toledo, R.A.; Shim, H. Lipid production by a mixed culture of oleaginous yeast and microalga from distillery and domestic mixed wastewater. Bioresour. Technol. 2014, 173, 132-139. [CrossRef]

65. McNeil, B.A.; Stuart, D.T. Lipomyces starkeyi: An emerging cell factory for production of lipids, oleochemicals and biotechnology applications. World J. Microbiol. Biotechnol. 2018, 34, 147. [CrossRef] [PubMed]

66. Wang, Q.; Sen, B.; Liu, X.; He, Y.; Xie, Y.; Wang, G. Enhanced saturated fatty acids accumulation in cultures of newly-isolated strains of Schizochytrium sp. and Thraustochytriidae sp. for large-scale biodiesel production. Sci. Total Environ. 2018, 631, 994-1004. [CrossRef] [PubMed] 
67. Spagnuolo, M.; Hussain, M.S.; Gambill, L.; Blenner, M. Alternative substrate metabolism in Yarrowia lipolytica. Front. Microbiol. 2018, 9, 1077. [CrossRef]

68. Spagnuolo, M.; Yaguchi, A.; Blenner, M. Oleaginous yeast for biofuel and oleochemical production. Curr. Opin. Biotechnol. 2019, 57, 73-81. [CrossRef]

69. Economou, C.N.; Aggelis, G.; Pavlou, S.; Vayenas, D.V. Single cell oil production from rice hulls hydrolysate. Bioresour. Technol. 2011, 102, 9737-9742. [CrossRef]

70. Kolouchová, I.; Mat'átková, O.; Sigler, K.; Masák, J.; Řezanka, T. Lipid accumulation by oleaginous and non-oleaginous yeast strains in nitrogen and phosphate limitation. Folia Microbiol. 2016, 61, 431-438. [CrossRef]

71. Kumar, D.; Singh, B.; Korstad, J. Utilization of lignocellulosic biomass by oleaginous yeast and bacteria for production of biodiesel and renewable diesel. Renew. Sustain. Energy Rev. 2017, 73, 654-671. [CrossRef]

72. Papanikolaou, S.; Aggelis, G. Lipids of oleaginous yeasts. Part II: Technology and potential applications. Eur. J. Lipid Sci. Technol. 2011, 113, 1052-1073. [CrossRef]

73. Yu, Y.; Xu, Z.; Chen, S.; Jin, M. Microbial lipid production from dilute acid and dilute alkali pretreated corn stover via Trichosporon dermatis. Bioresour. Technol. 2020, 295, 122253. [CrossRef] [PubMed]

74. Economou, C.N.; Aggelis, G.; Pavlou, S.; Vayenas, D.V. Modeling of single-Cell oil production under nitrogen-limited and substrate inhibition conditions. Biotechnol. Bioeng. 2011, 108, 1049-1055. [CrossRef] [PubMed]

75. Han, M.; Xu, Z.; Du, C.; Qian, H.; Zhang, W.G. Effects of nitrogen on the lipid and carotenoid accumulation of oleaginous yeast Sporidiobolus pararoseus. Bioprocess Biosyst. Eng. 2016, 39, 1425-1433. [CrossRef] [PubMed]

76. Fakas, S.; Papanikolaou, S.; Komaitis, M.; Aggelis, G. Organic nitrogen of tomato waste hydrolysate enhances glucose uptake and lipid accumulation in Cunninghamella echinulata. J. Appl. Microbiol. 2008, 105, 1062-1070. [CrossRef] [PubMed]

77. Fakas, S.; Čertik, M.; Papanikolaou, S.; Aggelis, G.; Komaitis, M.; Galiotou-Panayotou, M. $\gamma$-Linolenic acid production by Cunninghamella echinulata growing on complex organic nitrogen sources. Bioresour. Technol. 2008, 99, 5986-5990. [CrossRef] [PubMed]

78. Beopoulos, A.; Cescut, J.; Haddouche, R.; Uribelarrea, J.L.; Molina-Jouve, C.; Nicaud, J.M. Yarrowia lipolytica as a model for bio-oil production. Prog. Lipid Res. 2009, 48, 375-387. [CrossRef]

79. Huang, X.; Luo, H.; Mu, T.; Shen, Y.; Yuan, M.; Liu, J. Enhancement of lipid accumulation by oleaginous yeast through phosphorus limitation under high content of ammonia. Bioresour. Technol. 2018, 262, 9-14. [CrossRef]

80. Calvey, C.H.; Su, Y.K.; Willis, L.B.; McGee, M.; Jeffries, T.W. Nitrogen limitation, oxygen limitation, and lipid accumulation in Lipomyces starkeyi. Bioresour. Technol. 2016, 200, 780-788. [CrossRef]

81. Wang, X.; Fosse, H.K.; Li, K.; Chauton, M.S.; Vadstein, O.; Reitan, K.I. Influence of nitrogen limitation on lipid accumulation and EPA and DHA content in four marine microalgae for possible use in aquafeed. Front. Mar. Sci. 2019, 6, 95. [CrossRef]

82. Yodsuwan, N.; Sawayama, S.; Sirisansaneeyakul, S. Effect of nitrogen concentration on growth, lipid production and fatty acid pro fi les of the marine diatom Phaeodactylum tricornutum. Agric. Nat. Resour. 2017, 51, 190-197. [CrossRef]

83. Zhao, L.; Li, K.; Wang, Q.; Song, X.; Su, H.; Xie, B.; Zhang, X.; Huang, F.; Chen, X.; Zhou, B.; et al. Nitrogen starvation impacts the photosynthetic performance of Porphyridium cruentum as revealed by chlorophyll a fluorescence. Sci. Rep. 2017, 7, 1-11. [CrossRef]

84. Negi, S.; Barry, A.N.; Friedland, N.; Sudasinghe, N.; Subramanian, S.; Pieris, S.; Holguin, F.O.; Dungan, B.; Schaub, T.; Sayre, R. Impact of nitrogen limitation on biomass, photosynthesis, and lipid accumulation in Chlorella sorokiniana. Appl. Phycol. 2016, 28, 803-812. [CrossRef]

85. Srinuanpan, S.; Cheirsilp, B.; Prasertsan, P.; Kato, Y.; Asan, Y. Strategies to increase the potential use of oleaginous microalgae as biodiesel feedstocks: Nutrient starvations and cost-effective harvesting process. Renew. Energy 2018, 122, 507-516. [CrossRef]

86. Aratboni, H.A.; Rafiei, N.; Garcia-Granados, R.; Alemzadeh, A.; Morones-Ramírez, J.B. Biomass and lipid induction strategies in microalgae for biofuel production and other applications. Microb. Cell. Fact. 2019, 18, 1-17. [CrossRef] [PubMed]

87. An, M.; Gao, L.; Zhao, W.; Chen, W.; Li, M. Effects of nitrogen forms and supply mode on lipid production of microalga Scenedesmus obliquus. Energies 2020, 13, 697. [CrossRef] 
88. Bellou, S.; Moustogianni, A.; Makri, A.; Aggelis, G. Lipids containing polyunsaturated fatty acids synthesized by Zygomycetes grown on glycerol. Appl. Biochem. Biotechnol. 2012, 166, 146-158. [CrossRef] [PubMed]

89. Razzak, S.A.; Hossain, M.M.; Lucky, R.A.; Bassi, A.S.; Lasa, H.D. Integrated $\mathrm{CO}_{2}$ capture, wastewater treatment and biofuel production by microalgae culturing-A review. Renew. Sustain. Energy Rev. 2013, 27, 622-653. [CrossRef]

90. Cho, H.U.; Kim, Y.; Choi, Y.; Xu, X.; Shin, D.Y.; Park, J.M. Effects of pH control and concentration on microbial oil production from Chlorella vulgaris cultivated in the effluent of a low-cost organic waste fermentation system producing volatile fatty acids. Bioresour. Technol. 2015, 184, 245-250. [CrossRef]

91. Chiu, S.; Kao, C.; Tsai, M.; Ong, S.; Chen, C.; Lin, C. Lipid accumulation and $\mathrm{CO}_{2}$ utilization of Nannochloropsis oculata in response to $\mathrm{CO}_{2}$ aeration. Bioresour. Technol. 2009, 100, 833-838. [CrossRef] [PubMed]

92. Weldy, C.S.; Huesemann, M. Lipid production by Dunaliella salina in batch culture: Effects of nitrogen limitation and light intensity. Am. J. Undergrad. Res. 2014, 7, 115-122.

93. Pandit, P.R.; Fulekar, M.H.; Karuna, M.S.L. Effect of salinity stress on growth, lipid productivity, fatty acid composition, and biodiesel properties in Acutodesmus obliquus and Chlorella vulgaris. Environ. Sci. Pollut. Res. 2017, 24, 13437-13451. [CrossRef] [PubMed]

94. Converti, A.; Casazza, A.A.; Ortiz, E.Y.; Perego, P.; Borghi, M. Del. Effect of temperature and nitrogen concentration on the growth and lipid content of Nannochloropsis oculata and Chlorella vulgaris for biodiesel production. Chem. Eng. Process. 2009, 48, 1146-1151. [CrossRef]

95. Mattsson, L.; Lindehoff, E.; Olofsson, M.; Legrand, C. Boosting algal lipids: Diurnal shifts in temperature exceed the effects of nitrogen limitation. Eng. Rep. 2019, 1, e12067. [CrossRef]

96. Shi, K.; Gao, Z.; Shi, T.Q.; Song, P.; Ren, L.J.; Huang, H.; Ji, X.J. Reactive oxygen species-mediated cellular stress response and lipid accumulation in oleaginous microorganisms: The state of the art and future perspectives. Front. Microbiol. 2017, 8, 1-9. [CrossRef]

97. Zhang, S.; He, Y.; Sen, B.; Wang, G. Reactive oxygen species and their applications toward enhanced lipid accumulation in oleaginous microorganisms. Bioresour. Technol. 2020, 307, 123234. [CrossRef]

98. Ratledge, C. Biochemistry, stoichiometry, substrates and economics. In Single Cell Oil; Moreton, R.S., Ed.; Longman Scientific and Technical: Harlow, UK, 1988; pp. 33-70.

99. Papanikolaou, S.; Aggelis, G. Biotechnological valorization of biodiesel derived glycerol waste through production of single cell oil and citric acid by Yarrowia lipolytica. Lipid. Technol. 2009, 21, 83-87. [CrossRef]

100. Kim, J.H.; Block, D.E.; Mills, D.A. Simultaneous consumption of pentose and hexose sugars: An optimal microbial phenotype for efficient fermentation of lignocellulosic biomass. Appl. Microbiol. Biotechnol. 2010, 88, 1077-1085. [CrossRef]

101. Yamada, R.; Yamauchi, A.; Kashihara, T.; Ogino, H. Evaluation of lipid production from xylose and glucose/xylose mixed sugar in various oleaginous yeasts and improvement of lipid production by UV mutagenesis. Biochem. Eng. J. 2017, 128, 76-82. [CrossRef]

102. Dai, C.C.; Tao, J.; Xie, F.; Dai, Y.J.; Zhao, M. Biodiesel generation from oleaginous yeast Rhodotorula glutinis with xylose assimilating capacity. Afr. J. Biotechnol. 2007, 6, 2130-2134.

103. Joshua, C.J.; Dahl, R.; Benke, P.I.; Keasling, J.D. Absence of diauxie during simultaneous utilization of glucose and xylose by Sulfolobus acidocaldarius. J. Bacteriol. 2011, 193, 1293-1301. [CrossRef] [PubMed]

104. Poontawee, R.; Yongmanitchai, W.; Limtong, S. Efficient oleaginous yeasts for lipid production from lignocellulosic sugars and effects of lignocellulose degradation compounds on growth and lipid production. Process Biochem. 2017, 53, 44-60. [CrossRef]

105. Zhao, X.; Kong, X.; Hua, Y.; Feng, B.; Zhao, Z. Medium optimization for lipid production through co-fermentation of glucose and xylose by the oleaginous yeast Lipomyces starkeyi. Eur. J. Lipid Sci. Technol. 2008, 110, 405-412. [CrossRef]

106. Huang, C.; Chen, X.F.; Xiong, L.; Yang, X.Y.; Chen, X.D.; Ma, L.L.; Chen, Y. Microbial oil production from corncob acid hydrolysate by oleaginous yeast Trichosporon coremiiforme. Biomass Bioenergy 2013, 49, 273-278. [CrossRef]

107. Papanikolaou, S.; Diamantopoulou, P.; Chatzifragkou, A.; Philippoussis, A.; Aggelis, G. Suitability of low-cost sugars as substrates for lipid production by the fungus Thamnidium elegans. Energy Fuels 2010, 24, 4078-4086. [CrossRef]

108. Dey, P.; Maiti, M.K. Molecular characterization of a novel isolate of Candida tropicalis for enhanced lipid production. J. Appl. Microbiol. 2013, 114, 1357-1368. [CrossRef] 
109. Rodriguez, A.; Ersig, N.; Geiselman, G.M.; Seibel, K.; Simmons, B.A.; Magnuson, J.K.; Eudes, A.; Gladden, J.M. Conversion of depolymerized sugars and aromatics from engineered feedstocks by two oleaginous red yeasts. Bioresour. Technol. 2019, 286, 121365. [CrossRef]

110. Hu, C.; Wu, S.; Wang, Q.; Jin, G.; Shen, H.; Zhao, Z.K. Simultaneous utilization of glucose and xylose for lipid production by Trichosporon cutaneum. Biotechnol. Biofuels 2011, 4, 25. [CrossRef]

111. Yu, X.; Zheng, Y.; Xiong, X.; Chen, S. Co-utilization of glucose, xylose and cellobiose by the oleaginous yeast Cryptococcus curvatus. Biomass Bioenergy 2014, 71, 340-349. [CrossRef]

112. Fei, Q.; Fu, R.; Shang, L.; Brigham, C.J.; Chang, H.N. Lipid production by microalgae Chlorella protothecoides with volatile fatty acids (VFAs) as carbon sources in heterotrophic cultivation and its economic assessment. Bioproc. Biosystems. Eng. 2015, 38, 691-700. [CrossRef] [PubMed]

113. Poontawee, R.; Yongmanitchai, W.; Limtong, S. Lipid production from a mixture of sugarcane top hydrolysate and biodiesel- derived crude glycerol by the oleaginous red yeast, Rhodosporidiobolus fluvialis. Process. Biochem. 2018, 66, 150-161. [CrossRef]

114. Yang, X.; Jin, G.; Gong, Z.; Shen, H.; Song, Y.; Bai, F.; Zhao, Z.K. Simultaneous utilization of glucose and mannose from spent yeast cell mass for lipid production by Lipomyces starkeyi. Bioresour. Technol. 2014, 158, 383-387. [CrossRef]

115. Patel, A.; Pruthi, V.; Singh, R.P.; Pruthi, P.A. Synergistic effect of fermentable and non-fermentable carbon sources enhances TAG accumulation in oleaginous yeast Rhodosporidium kratochvilovae HIMPA1. Bioresour. Technol. 2015, 188, 136-144. [CrossRef]

116. Tanimura, A.; Takashima, M.; Sugita, T.; Endoh, R.; Ohkuma, M.; Kishino, S.; Ogawa, J.; Shima, J. Lipid production through simultaneous utilization of glucose, xylose, and l-arabinose by Pseudozyma hubeiensis: A comparative screening study. AMB Express 2016, 6, 58. [CrossRef]

117. Patel, A.; Sindhu, D.K.; Arora, N.; Singh, R.P.; Pruthi, V.; Pruthi, P.A. Biodiesel production from non-edible lignocellulosic biomass of Cassia fistula L. fruit pulp using oleaginous yeast Rhodosporidium kratochvilovae HIMPA1. Bioresour. Technol. 2015, 197, 91-98. [CrossRef] [PubMed]

118. Tsigie, Y.A.; Wang, C.Y.; Truong, C.T.; Ju, Y.H. Lipid production from Yarrowia lipolytica Po1g grown in sugarcane bagasse hydrolysate. Bioresour. Technol. 2011, 102, 9216-9222. [CrossRef] [PubMed]

119. Valdés, G.; Mendonça, R.T.; Parra, C.; Aggelis, G. Patterns of lignocellulosic sugar assimilation and lipid production by newly isolated yeast strains from Chilean Valdivian forest. Appl. Biochem. Biotechnol. 2020. [CrossRef] [PubMed]

120. Papanikolaou, S.; Sarantou, S.; Komaitis, M.; Aggelis, G. Repression of reserve lipid turnover in Cunninghamella echinulata and Mortierella isabellina cultivated in multiple-limited media. J. Appl. Microbiol. 2004, 97, 867-875. [CrossRef]

121. Arous, F.; Mechichi, T.; Nasri, M.; Aggelis, G. Fatty acid biosynthesis during the life cycle of Debaryomyces etchellsii. Microbiology 2016, 162, 1080-1090. [CrossRef]

122. Zhang, H.; Zhang, L.; Chen, H.; Chen, Y.Q.; Chen, W.; Song, Y.; Ratledge, C. Enhanced lipid accumulation in the yeast Yarrowia lipolytica by over-expression of ATP: Citrate lyase from Mus musculus. J. Biotechnol. 2014, 192, 78-84. [CrossRef] [PubMed]

123. Dulermo, T.; Lazar, Z.; Dulermo, R.; Rakicka, M.; Haddouche, R.; Nicaud, J.M. Analysis of ATP-citrate lyase and malic enzyme mutants of Yarrowia lipolytica points out the importance of mannitol metabolism in fatty acid synthesis. Biochim. Biophys. Acta 2015, 1851, 1107-1117. [CrossRef]

124. Blatti, J.L.; Michaud, J.; Burkart, M.D. Engineering fatty acid biosynthesis in microalgae for sustainable biodiesel. Curr. Opin. Chem. Biol. 2013, 17, 496-505. [CrossRef] [PubMed]

125. Cronan, J.E.; Thomas, J. Bacterial fatty acid synthesis and its relationships with polyketide synthetic pathways. Methods Enzymol. 2009, 459, 395-433.

126. Spaans, S.K.; Weusthuis, R.A.; van der Oost, J.; Kengen, S.W.M. NADPH-generating systems in bacteria and archaea. Front. Microbiol. 2015, 6, 742. [CrossRef] [PubMed]

127. Wasylenko, T.M.; Ahn, W.S.; Stephanopoulos, G. The oxidative pentose phosphate pathway is the primary source of NADPH for lipid overproduction from glucose in Yarrowia lipolytica. Metab. Eng. 2015, 30, 27-39. [CrossRef]

128. Ratledge, $\mathrm{C}$. The role of malic enzyme as the provider of NADPH in oleaginous microorganisms: A reappraisal and unsolved problems. Biotechnol. Let. 2014, 36, 1557-1568. [CrossRef] 
129. Bommareddy, R.R.; Sabra, W.; Maheshwari, G.; Zeng, A.P. Metabolic network analysis and experimental study of lipid production in Rhodosporidium toruloides grown on single and mixed substrates. Microb. Cell. Factories 2015, 14, 36. [CrossRef]

130. Park, Y.; Han, G.S.; Mileykovskaya, E.; Garrett, T.A.; Carman, G.M. Altered lipid synthesis by lack of yeast Pah1 phosphatidate phosphatase reduces chronological life span. J. Biol. Chem. 2015, 290, 25382-25394. [CrossRef]

131. Fakas, S. Lipid biosynthesis in yeasts: A comparison of the lipid biosynthetic pathway between the model nonoleaginous yeast Saccharomyces cerevisiae and the model oleaginous yeast Yarrowia lipolytica. Eng. Life Sci. 2017, 17, 292-302. [CrossRef]

132. Hardman, D.; McFalls, D.; Fakas, S. Characterization of phosphatidic acid phosphatase activity in the oleaginous yeast Yarrowia lipolytica and its role in lipid biosynthesis. Yeast 2017, 34, 83-91. [CrossRef] [PubMed]

133. Dulermo, T.; Nicaud, J.M. Involvement of the G3P shuttle and $\beta$-oxidation pathway in the control of TAG synthesis and lipid accumulation in Yarrowia lipolytica. Metab. Eng. 2011, 13, 482-491. [CrossRef] [PubMed]

134. Ruan, Z.; Zanotti, M.; Zhong, Y.; Liao, W.; Ducey, C.; Liu, Y. Co-hydrolysis of lignocellulosic biomass for microbial lipid accumulation. Biotechnol. Bioeng. 2013, 110, 1039-1049. [CrossRef]

135. Qian, X.; Gorte, O.; Chen, L.; Zhang, W.; Dong, W.; Ma, J.; Jiang, M.; Xin, F.; Ochsenreither, K. Co-production of single cell oil and gluconic acid using oleaginous Cryptococcus podzolicus DSM 27192. Biotechnol. Biofuels 2019, 12, 1-9. [CrossRef]

136. Papanikolaou, S.; Galiotou-Panayotou, M.; Fakas, S.; Komaitis, M.; Aggelis, G. Citric acid production by Yarrowia lipolytica cultivated on olive-mill wastewater-based media. Bioresour. Technol. 2008, 99, 2419-2428. [CrossRef] [PubMed]

137. Papanikolaou, S.; Chatzifragkou, A.; Fakas, S.; Galiotou-panayotou, M.; Komaitis, M.; Nicaud, J.; Aggelis, G. Biosynthesis of lipids and organic acids by Yarrowia lipolytica strains cultivated on glucose. Eur. J. Lipid. Sci. Technol. 2009, 111, 1221-1232. [CrossRef]

138. Papanikolaou, S.; Kampisopoulou, E.; Blanchard, F.; Rondags, E.; Gardeli, C.; Koutinas, A.A.; Chevalot, I.; Aggelis, G. Production of secondary metabolites through glycerol fermentation under carbon-excess conditions by the yeasts Yarrowia lipolytica and Rhodosporidium toruloides. Eur. J. Lipid. Sci. Technol. 2017, 119, 1600507. [CrossRef]

139. Papanikolaou, S.; Rontou, M.; Belka, A.; Athenaki, M.; Gardeli, C.; Mallouchos, A.; Kalantzi, O.; Koutinas, A.A.; Kookos, I.K.; Zeng, A.P.; et al. Conversion of biodiesel-derived glycerol into biotechnological products of industrial significance by yeast and fungal strains. Eng. Life Sci. 2017, 17, 262-281. [CrossRef]

140. Wang, Z.; Xu, H.; Wang, G.; Chi, Z.; Chi, Z. Disruption of the MIG1 gene enhances lipid biosynthesis in the oleaginous yeast Yarrowia lipolytica ACA-DC 50109. BBA-Mol. Cell Biol. Lipids 2013, 1831, 675-682. [CrossRef]

141. Lazar, Z.; Dulermo, T.; Neuvéglise, C.; Crutz-Le Coq, A.M.; Nicaud, J.M. Hexokinase-A limiting factor in lipid production from fructose in Yarrowia lipolytica. Metab. Eng. 2014, 2, 89-99. [CrossRef]

142. Zhang, H.; Zhang, L.; Chen, H.; Chen, W.; Ratledge, C.; Song, Y.; Chen, W. Regulatory properties of malic enzyme in the oleaginous yeast, Yarrowia lipolytica, and its non-involvement in lipid accumulation. Biotechnol. Lett. 2013, 35, 2091-2098. [CrossRef] [PubMed]

143. Aguilar, L.R.; Pardo, J.P.; Lomelí, M.M.; Bocardo, O.I.L.; Juárez Oropeza, M.A.; Guerra Sánchez, G. Lipid droplets accumulation and other biochemical changes induced in the fungal pathogen Ustilago maydis under nitrogen-starvation. Arch. Microbiol. 2017, 199, 1195-1209. [CrossRef] [PubMed]

144. Zhang, S.; Skerker, J.M.; Rutter, C.D.; Maurer, M.J.; Arkin, A.P.; Rao, C.V. Engineering Rhodosporidium toruloides for increased lipid production. Biotechnol. Bioeng. 2016, 113, 1056-1066. [CrossRef]

145. Shi, S.; Chen, Y.; Siewers, V.; Nielsen, J. Improving production of malonyl coenzyme a-derived metabolites by abolishing Snf1-dependent regulation of Acc1. MBio 2014, 5, 1-8. [CrossRef] [PubMed]

146. Wang, J.; Gao, Q.; Zhang, H.; Bao, J. Inhibitor degradation and lipid accumulation potentials of oleaginous yeast Trichosporon cutaneum using lignocellulose feedstock. Bioresour. Technol. 2016, 218, 892-901. [CrossRef]

147. Li, Z.; Sun, H.; Mo, X.; Li, X.; Xu, B.; Tian, P. Overexpression of malic enzyme (ME) of Mucor circinelloides improved lipid accumulation in engineered Rhodotorula glutinis. Appl. Microbiol. Biotechnol. 2013, 97, 4927-4936. [CrossRef] 
148. Xue, J.; Niu, Y.; Huang, T.; Yang, W.; Liu, J.; Li, H. Genetic improvement of the microalga Phaeodactylum tricornutum for boosting neutral lipid accumulation. Metab. Eng. 2015, 27, 1-9. [CrossRef]

149. Runguphan, W.; Keasling, J.D. Metabolic engineering of Saccharomyces cerevisiae for production of fatty acid-derived biofuels and chemicals. Metab. Eng. 2014, 21, 103-113. [CrossRef]

150. Chuang, L.; Chen, D.; Nicaud, J.; Madzak, C.; Chen, Y.; Huang, Y. Co-expression of heterologous desaturase genes in Yarrowia lipolytica. N. Biotechnol. 2010, 27, 277-282. [CrossRef]

151. Xie, D.; Jackson, E.N.; Zhu, Q. Sustainable source of omega-3 eicosapentaenoic acid from metabolically engineered Yarrowia lipolytica: From fundamental research to commercial production. Appl. Microbiol. Biotechnol. 2015, 99, 1599-1610. [CrossRef]

152. Saenge, C.; Cheirsilp, B.; Suksaroge, T.T.; Bourtoom, T. Efficient concomitant production of lipids and carotenoids by oleaginous red yeast Rhodotorula glutinis cultured in palm oil mill effluent and application of lipids for biodiesel production. Biotechnol. Bioprocess Eng. 2011, 16, 23-33. [CrossRef]

153. Xu, J.; Du, W.; Zhao, X.; Zhang, G.; Liu, D. Microbial oil production from various carbon sources and its use for biodiesel preparation. Biofuel. Bioprod. Bior. 2013, 7, 65-77. [CrossRef]

154. Brennan, L.; Owende, P. Biofuels from microalgae-A review of technologies for production, processing, and extractions of biofuels and co-products. Renew. Sust. Energy Rev. 2010, 14, 557-577. [CrossRef]

155. Qadeer, S.; Khalid, A.; Mahmood, S.; Anjum, M.; Ahmad, Z. Utilizing oleaginous bacteria and fungi for cleaner energy production. J. Clean. Prod. 2017, 168, 917-928. [CrossRef]

156. Shruthi, P.; Rajeshwari, T.; Mrunalini, B.R.; Girish, V.; Girisha, S.T. Evaluation of oleaginous bacteria for potential biofuel. Int. J. Curr. Microbiol. Appl. Sci. 2014, 3, 47-57.

157. Lin, C.Y.; Lin, Y.W. Fuel characteristics of biodiesel produced from a high-acid oil from soybean soapstock by supercritical-methanol transesterification. Energies 2012, 5, 2370-2380. [CrossRef]

158. Ekpeni, L.E.N.; Benyounis, K.Y.; Nkem-ekpeni, F.F.; Stokes, J.; Olabi, A.G. Underlying factors to consider in improving energy yield from biomass source through yeast use on high-pressure homogenizer (hph). Energy 2015, 81, 74-83. [CrossRef]

159. Vaz, S., Jr. Biomass and the Green Chemistry, 1st ed.; Springer: Brasília, Brazil, 2018; p. 264.

160. Fatma, S.; Hameed, A.; Noman, M.; Ahmed, T.; Sohail, I.; Shahid, M.; Tariq, M.; Tabassum, R. Lignocellulosic biomass: A sustainable bioenergy source for future. Protein Pept. Lett. 2018, 25. [CrossRef]

161. Monlau, F.; Sambusiti, C.; Barakat, A.; Quéméneur, M.; Trably, E.; Steyer, J.; Carrère, H. Do furanic and phenolic compounds of lignocellulosic and algae biomass hydrolysate inhibit anaerobic mixed cultures? A comprehensive review. Biotechnol. Adv. 2014, 32, 934-951. [CrossRef]

162. Carrillo, I.; Teixeira, R.; Ago, M.; Rojas, O. Comparative study of cellulosic components isolated from different Eucalyptus species. Cellulose 2018, 25, 1011-1029. [CrossRef]

163. Borand, M.N.; Karaosmanoğlu, F. Effects of organosolv pretreatment conditions for lignocellulosic biomass in biorefinery applications: A review. J. Renew. Sustain. Energy 2018, 10, 033104. [CrossRef]

164. Yoo, C.G.; Meng, X.; Pu, Y.; Ragauskas, A.J. The critical role of lignin in lignocellulosic biomass conversion and recent pretreatment strategies: A comprehensive review. Bioresour. Technol. 2020, 301, 122784. [CrossRef]

165. Usmani, Z.; Sharma, M.; Gupta, P.; Karpichev, Y.; Gathergood, N.; Bhat, R.; Gupta, V.K. Ionic liquid based of lignocellulosic biomass for enhanced bioconversion. Bioresour. Technol. 2020, 304, 123003. [CrossRef] [PubMed]

166. Fengel, D.; Wegener, G. Wood: Chemistry, Ultrastructure, Reactions, 1st ed.; Verlag Kessel: Remagen, Germany, 2003; p. 613.

167. Lim, W.; Lee, J. Influence of pretreatment condition on the fermentable sugar production and enzymatic hydrolysis of dilute acid-pretreated mixed softwood. Bioresour. Technol. 2013, 140, 306-311. [CrossRef] [PubMed]

168. Zhang, T.; Jiang, D.; Zhang, H.; Lee, D.; Zhang, Z.; Zhang, Q.; Jing, Y.; Zhang, Y.; Xia, C. Effects of different pretreatment methods on the structural characteristics, enzymatic saccharification and photo-fermentative bio-hydrogen production performance of corn straw. Bioresour. Technol. 2020, 304, 122999. [CrossRef]

169. Lima, D.R.; Silveira, M.H.L.; Del Rio, L.; Ramos, L.P. Pretreatment processes for cellulosic ethanol production: Processes integration and modeling for the utilization of lignocellulosics such as sugarcane straw. In Green Fuels Technology, 1st ed.; Soccol, C.R., Brar, S.K., Faulds, C., Ramos, L.P., Eds.; Springer: New York, NY, USA, 2016; Volume 1, pp. 107-131. 
170. Gellerstedt, G. The worldwide wood resource. In Pulp and Paper Chemistry and Technology Wood Chemistry and Wood Biotechnology; Ek, M., Gellerstedt, G., Henriksson, G., Eds.; Walter de Gruyter: Berlin, Germany, 2009; p. 321.

171. Brandt, A.; Gräsvik, J.; Hallett, J.P.; Welton, T. Deconstruction of lignocellulosic biomass with ionic liquids. Green Chem. 2013, 15, 550-583. [CrossRef]

172. Woiciechowski, A.L.; Neto, C.J.D.; Porto de Souza, L.; Vandenberghe, L.P.; Neto, D.C.; Sydney, A.C.; Letti, L.A.; Karp, S.G.; Torres, L.A.; Soccol, C.R. Lignocellulosic biomass: Acid and alkaline pretreatments and their effects on biomass recalcitrance-conventional processing and recent advances. Bioresour. Technol. 2020, 304, 122848. [CrossRef]

173. Arantes, V.; Goodell, B. Current understanding of brown-rot fungal biodegradation mechanisms: A review. In Deterioration and Protection of Sustainable Biomaterials; Schultz, T.P., Goodell, B., Nicholas, D., Eds.; American Chemical Society: Washington, DC, USA, 2014; pp. 3-21.

174. Cragg, S.M.; Beckham, G.T.; Bruce, N.C.; Bugg, T.D.H.; Distel, D.L.; Dupree, P.; Etxabe, A.G.; Goodell, B.S.; Jellison, J.; Mcgeehan, J.E.; et al. Lignocellulose degradation mechanisms across the Tree of Life. Curr. Opin. Chem. Biol. 2015, 29, 108-119. [CrossRef]

175. Potumarthi, R.; Raju, R.; Nayak, P.; Jetty, A. Simultaneous pretreatment and sacchariffication of rice husk by Phanerochete chrysosporium for improved production of reducing sugars. Bioresour. Technol. 2013, 128, 113-117. [CrossRef]

176. Rodríguez-Couto, S. Industrial and environmental applications of white-rot fungi. Mycosphere 2017, 8 , 456-466. [CrossRef]

177. Martínez-patiño, J.C.; Lu-chau, T.A.; Gullón, B.; Ruiz, E.; Romero, I.; Castro, E.; Lema, J.M. Application of a combined fungal and diluted acid pretreatment on olive tree biomass. Ind. Crop. Prod. 2018, 121, 10-17. [CrossRef]

178. Daniel, G. Fungal and bacterial biodegradation: White rots, brown rots, soft rots, and bacteria. ACS Symp. Ser. 2014, 1158, 23-58. [CrossRef]

179. Hamid, A.M.; Solbiati, J.O.; Cann, I.K.O. Insights into lignin degradation and its potential industrial applications. Adv. Appl. Microbiol. 2013, 82, 1-28. [CrossRef]

180. Fonseca, M.I.; Fariña, J.I.; Castrillo, M.L.; Rodríguez, M.D.; Nuñez, C.E.; Villalba, L.L.; Zapata, P.D. Biopulping of wood chips with Phlebia brevispora BAFC 633 reduces lignin content and improves pulp quality. Int. Biodeterior. Biodegr. 2014, 90, 29-35. [CrossRef]

181. Barakat, A.; Mayer-laigle, C.; Solhy, A.; Arancon, R.A.D.; Vries, H.; Luque, R. Mechanical pretreatments of lignocellulosic biomass: Towards facile and environmentally sound technologies for biofuels production. RSC Adv. 2014, 4, 48109-48127. [CrossRef]

182. Mayer-Laigle, C.; Rajaonarivony, R.K.; Blanc, N.; Rouau, X. Comminution of dry lignocellulosic biomass: Part II. Technologies, improvement of milling performances, and security issues. Bioengineering 2018, 5, 50. [CrossRef] [PubMed]

183. Barakat, A.; Monlau, F.; Solhy, A.; Carrere, H. Mechanical dissociation and fragmentation of lignocellulosic biomass: Effect of initial moisture, biochemical and structural proprieties on energy requirement. Appl. Energy 2015, 142, 240-246. [CrossRef]

184. Agbor, V.B.; Cicek, N.; Sparling, R.; Berlin, A.; Levin, D.B. Biomass pretreatment: Fundamentals toward application. Biotechnol. Adv. 2011, 29, 675-685. [CrossRef]

185. Brodeur, G.; Yau, E.; Badal, K.; Collier, J.; Ramachandran, K.B.; Ramakrishnan, S. Chemical and physicochemical pretreatment of lignocellulosic biomass: A review. Enzyme Res. 2011, 2011, 1-17. [CrossRef]

186. Singh, J.; Suhag, M.; Dhaka, A. Augmented digestion of lignocellulose by steam explosion, acid and alkaline pretreatment methods: A review. Carbohydr. Polym. 2015, 117, 624-631. [CrossRef]

187. Solarte-Toro, J.C.; Romero-García, J.M.; Martínez-Patiño, J.C.; Ruiz-Ramos, E.; Castro-Galiano, E.; Cardona-Alzate, C.A. Acid pretreatment of lignocellulosic biomass for energy vectors production: A review focused on operational conditions and techno-economic assessment for bioethanol production. Renew. Sustain. Energy Rev. 2019, 107, 587-601. [CrossRef]

188. Kumar, B.; Bhardwaj, N.; Agrawal, K.; Chaturvedi, V.; Verma, P. Current perspective on pretreatment technologies using lignocellulosic biomass: An emerging biorefinery concept. Fuel Process. Technol. 2020, 199, 106244. [CrossRef] 
189. Rigual, V.; Santos, T.M.; Domínguez, J.C.; Alonso, M.V.; Oliet, M.; Rodriguez, F. Evaluation of hardwood and softwood fractionation using autohydrolysis and ionic liquid microwave pretreatment. Biomass Bioenergy 2018, 117, 190-197. [CrossRef]

190. Zhao, X.; Cheng, K.; Liu, D. Organosolv pretreatment of lignocellulosic biomass for enzymatic hydrolysis. Appl. Microbiol. Biotechnol. 2009, 82, 815-827. [CrossRef]

191. Hsu, T.; Guo, G.; Chen, W.; Hwang, W. Effect of dilute acid pretreatment of rice straw on structural properties and enzymatic hydrolysis. Bioresour. Technol. 2010, 101, 4907-4913. [CrossRef]

192. López-Linares, J.C.; Cara, C.; Moya, M.; Ruiz, E.; Castro, E.; Romero, I. Fermentable sugar production from rapeseed straw by dilute phosphoric acid pretreatment. Ind. Crops Prod. 2013, 50, 525-531. [CrossRef]

193. Wang, G.S.; Lee, J.; Zhu, J.Y.; Jeffries, T.W. Dilute Acid Pretreatment of corncob for efficient sugar production. Appl. Biochem. Biotechnol. 2011, 163, 658-668. [CrossRef]

194. Amnuaycheewa, P.; Hengaroonprasan, R.; Rattanaporn, K.; Kirdponpattara, S.; Cheenkachorn, K.; Sriariyanund, M. Enhancing enzymatic hydrolysis and biogas production from rice straw by pretreatment with organic acids. Ind. Crop. Prod. 2016, 87, 247-254. [CrossRef]

195. Noparat, P.; Prasertsan, P.; O.-thong, S.; Pan, X. Dilute Acid Pretreatment of oil palm trunk biomass at high temperature for enzymatic hydrolysis. Energy Proc. 2015, 79, 924-929. [CrossRef]

196. Yan, Y.; Zhang, C.; Lin, Q.; Wang, X.; Cheng, B.; Li, H.; Ren, J. Microwave-assisted oxalic acid pretreatment for the enhancing of enzyme hydrolysis in the production of xylose and arabinose from bagasse. Molecules 2018, 23, 862. [CrossRef]

197. Dziekonska-Kubczak, U.; Berłowska, J.; Dziugan, P.; Patelski, P.; Pielech-Przybylska, K.; Balcerek, M. Nitric acid pretreatment of Jerusalem artichoke stalks for enzymatic saccharification and biorthanol production. Energies 2018, 11, 2153. [CrossRef]

198. Sahu, S.; Pramanik, K. Evaluation and optimization of organic acid pretreatment of cotton gin waste for enzymatic hydrolysis and bioethanol production. Appl. Biochem. Biotechnol. 2018, 186, 1047-1060. [CrossRef] [PubMed]

199. Wei, W.; Wu, S.; Liu, L. Enzymatic saccharification of dilute acid pretreated eucalyptus chips for fermentable sugar production. Bioresour. Technol. 2012, 110, 302-307. [CrossRef]

200. Zhang, L.; Pu, Y.; Cort, J.R.; Ragauskas, A.J.; Yang, B. Revealing the molecular structural transformation of hardwood and softwood in dilute acid flow through pretreatment. ACS Sustain. Chem. Eng. 2016, 4, 6618-6628. [CrossRef]

201. Yu, X.; Zheng, Y.; Dorgan, K.M.; Chen, S. Oil production by oleaginous yeasts using the hydrolysate from pretreatment of wheat straw with dilute sulfuric acid. Bioresour. Technol. 2011, 102, 6134-6140. [CrossRef] [PubMed]

202. Sahoo, D.; Beevi, S.; Kumar, A.; Pandey, A.; Sankar, M.; Sukumaran, R.K. Effect of dilute acid pretreatment of wild rice grass (Zizania latifolia) from Loktak Lake for enzymatic hydrolysis. Bioresour. Technol. 2018, 253, 252-255. [CrossRef] [PubMed]

203. Yu, Z.; Du, Y.; Shang, X.; Zheng, Y.; Zhou, J. Enhancing fermentable sugar yield from cassava residue using a two-step dilute ultra-low acid pretreatment process. Ind. Crop. Prod. 2018, 124, 555-562. [CrossRef]

204. Janga, K.K.; Hägg, M.-B.; Moe, S.T. Influence of acid concentration, temperature, and time on the concentrated sulfuric acid hydrolysis of pinewood and aspenwood: A statistical approach. BioResources 2012, 7, 391-411. [CrossRef]

205. Bravo, C.; Garcés, D.; Faba, L.; Sastre, H.; Ordóñez, S. Selective arabinose extraction from Pinus sp. sawdust by two-step soft acid hydrolysis. Ind. Crop. Prod. 2017, 104, 229-236. [CrossRef]

206. He, Y.; Zhang, J.; Bao, J. Dry dilute acid pretreatment by co-currently feeding of corn stover feedstock and dilute acid solution without impregnation. Bioresour. Technol. 2014, 158, 360-364. [CrossRef]

207. Gupta, R.; Lee, Y.Y. Pretreatment of corn stover and hybrid poplar by sodium hydroxide and hydrogen peroxide. Biotechnol. Prog. 2010, 26, 1180-1186. [CrossRef] [PubMed]

208. Chen, B.; Chen, S.; Wang, H. Use of different alkaline pretreatments and enzyme models to improve low-cost cellulosic biomass conversion. Biomass Bioenergy 2012, 39, 182-191. [CrossRef]

209. Sakuragi, K.; Igarashi, K.; Samejima, M. Application of ammonia pretreatment to enable enzymatic hydrolysis of hardwood biomass. Polym. Degrad. Stab. 2018, 148, 19-25. [CrossRef] 
210. An, S.; Li, W.; Liu, Q.; Xia, Y.; Zhang, T.; Huang, F.; Lin, Q.; Chen, L. Combined dilute hydrochloric acid and alkaline wet oxidation pretreatment to improve sugar recovery of corn stover. Bioresour. Technol. 2019, 271, 283-288. [CrossRef]

211. Zu, S.; Li, W.; Zhang, M.; Li, Z.; Wang, Z.; Jameel, H.; Chang, H. Pretreatment of corn stover for sugar production using dilute hydrochloric acid followed by lime. Bioresour. Technol. 2014, 152, 364-370. [CrossRef]

212. Yang, M.; Lan, M.; Gao, X.; Dou, Y.; Zhang, X. Sequential dilute acid/alkali pretreatment of corncobs for ethanol production. Energy Sources Part A Recover. Util. Environ. Eff. 2019, 1-10. [CrossRef]

213. Lee, J.W.; Kim, J.Y.; Jang, H.M.; Lee, M.W.; Park, J.M. Sequential dilute acid and alkali pretreatment of corn stover: Sugar recovery efficiency and structural characterization. Bioresour. Technol. 2015, 182, 296-301. [CrossRef]

214. Cybulska, I.; Brudecki, G.P.; Zembrzuska, J.; Schmit, J.E.; Lopez, C.G.B.; Thomsen, M.H. Organosolv delignification of agricultural residues (date palm fronds, Phoenix dactylifera L.) of the United Arab Emirates. Appl. Energy 2016, 185, 1040-1050. [CrossRef]

215. Koo, B.; Park, N.; Jeong, H.; Choi, J.; Yeo, H.; Choi, I. Characterization of by-products from organosolv pretreatments of yellow poplar wood (Liriodendron tulipifera) in the presence of acid and alkali catalysts. J. Ind. Eng. Chem. 2011, 17, 18-24. [CrossRef]

216. Shahbazi, A.; Zhang, B. Dilute and concentrated acid hydrolysis of lignocellulosic biomass. In Bioalcohol Production: Biochemical Conversion of Lignocellulosic Biomass; Waldron, K.W., Ed.; Woodhead: Sawston, Cambridge, UK, 2010; p. 496.

217. Maurya, D.P.; Singla, A.; Negi, S. An overview of key pretreatment processes for biological conversion of lignocellulosic biomass to bioethanol. 3 Biotech. 2015, 5, 597-609. [CrossRef]

218. Qi, W.; He, C.; Wang, Q.; Liu, S.; Yu, Q.; Wang, W.; Leksawasdi, N.; Wang, C.; Yuan, Z. Carbon-based solid acid pretreatment in corncob saccharification: Specific xylose production and efficient enzymatic hydrolysis. ACS Sustain. Chem. Eng. 2018, 6, 3640-3648. [CrossRef]

219. Xu, J.; Sun, R.C. Recent advances in alkaline pretreatment of lignocellulosic biomass. In Biomass Fractionation Technologies for A Lignocellulosic Feedstock Based Biorefiner; Mussatto, S., Ed.; Elsevier: Atlanta, GA, USA, 2016; pp. 311-324.

220. Nitsos, C.; Rova, U. Organosolv Fractionation of softwood biomass for biofuel and biorefinery applications. Energies 2018, 11, 50. [CrossRef]

221. Nargotra, P.; Sharma, V.; Gupta, M.; Kour, S.; Bajaj, B.K. Application of ionic liquid and alkali pretreatment for enhancing saccharification of sunflower stalk biomass for potential biofuel-ethanol production. Bioresour. Technol. 2018, 267, 560-568. [CrossRef] [PubMed]

222. Castro, E.; Nieves, I.U.; Mullinnix, M.T.; Sagues, W.J.; Hoffman, R.W.; Fernández-Sandoval, M.T.; Tian, Z.; Rockwood, D.L.; Tamang, B.; Ingram, L.O. Optimization of dilute-phosphoric-acid steam pretreatment of Eucalyptus benthamii for biofuel production. Appl. Energy 2014, 125, 76-83. [CrossRef]

223. Sitepu, I.R.; Garay, L.A.; Enriquez, L.; Fry, R.; Butler, J.H.; Lopez, J.M.; Kanti, A.; Faulina, S.A.; Nugroho, A.J.; Simmons, B.A.; et al. 1-Ethyl-3-methylimidazolium tolerance and intracellular lipid accumulation of 38 oleaginous yeast species. Appl. Microbiol. Biotechnol. 2017, 101, 8621-8631. [CrossRef]

224. Abdul, P.M.; Jahim, J.; Harun, S.; Markom, M.; Aminah, N.; Hassan, O.; Balan, V.; Dale, B.E.; Mohd-Nor, M.T. Effects of changes in chemical and structural characteristic of ammonia fibre expansion (AFEX) pretreated oil palm empty fruit bunch fiber on enzymatic saccharification and fermentability for biohydrogen. Bioresour. Technol. 2016, 211, 200-208. [CrossRef]

225. Kim, S.M.; Dien, B.S.; Tumbleson, M.E.; Rausch, K.D.; Singh, V. Improvement of sugar yields from corn stover using sequential hot water pretreatment and disk milling. Bioresour. Technol. 2016, 216, 706-713. [CrossRef]

226. Wells, J.M.; Drielak, E.; Surendra, K.C.; Khanal, S. Hot water pretreatment of lignocellulosic biomass: Modeling the effects of temperature, enzyme and biomass loadings on sugar yield. Bioresour. Technol. 2020, 300, 122593. [CrossRef]

227. Ethaib, S.; Omar, R.; Kamal, M.M.; Radiah, D. Microwave-assisted pretreatment of lignocellulosic biomass: A review. J. Eng. Sci. Technol. 2015, 10, 97-109.

228. Huang, C.; Zong, M.; Wu, H.; Liu, Q. Microbial oil production from rice straw hydrolysate by Trichosporon fermentans. Bioresour. Technol. 2009, 100, 4535-4538. [CrossRef] 
229. Zhao, X.; Peng, F.; Du, W.; Liu, C.; Liu, D. Effects of some inhibitors on the growth and lipid accumulation of oleaginous yeast Rhodosporidium toruloides and preparation of biodiesel by enzymatic transesterification of the lipid. Bioproc. Biosyst. Eng. 2012, 35, 993-1004. [CrossRef] [PubMed]

230. Banerjee, N.; Bhatnagar, R.; Viswanathan, L. Inhibition of glycolysis by furfural in Saccharomyces cerevisiae. Eur. J. Appl. Microbiol. 1981, 11, 226-228. [CrossRef]

231. Modig, T.; Liden, G.; Taherzadeh, M.J. Inhibition effects of furfural on alcohol dehydrogenase, aldehyde dehydrogenase and pyruvate dehydrogenase. Biochem. J. 2002, 363, 769-776. [CrossRef] [PubMed]

232. Almeida, J.R.M.; Bertilsson, M.; Hahn-Hägerdal, B.; Lidén, G.; Gorwa-Grauslund, M.F. Carbon fluxes of xylose-consuming Saccharomyces cerevisiae strains are affected differently by NADH and NADPH usage in HMF reduction. Appl. Microbiol. Biotechnol. 2009, 84, 751-761. [CrossRef] [PubMed]

233. Quintero, A.; Rinco, L.E.; Cardona, C.A. Production of bioethanol from agroindustrial residues as feedstocks. In Biofuels Alternative Feedstocks and Conversion Processes; Pandey, A., Larroche, C., Ricke, S., Dussap, C.G., Gnansounou, E., Eds.; Academic Press: Cambridge, MA, USA, 2011; pp. 251-285.

234. Tu, W.; Hallett, J.P. Recent advances in the pretreatment of lignocellulosic biomass. Curr. Opin. Green Sustain. Chem. 2019, 20,11-17. [CrossRef]

235. Chen, X.; Li, Z.; Zhang, X.; Hu, F.; Ryu, D.D.Y.; Bao, J. Screening of oleaginous yeast strains tolerant to lignocellulose degradation compounds. Appl. Biochem. Biotechnol. 2009, 159, 591-604. [CrossRef]

236. Hu, C.; Zhao, X.; Zhao, J.; Wu, S.; Zhao, Z.K. Effects of biomass hydrolysis by-products on oleaginous yeast Rhodosporidium toruloides. Bioresour. Technol. 2009, 100, 4843-4847. [CrossRef] [PubMed]

237. Brandenburg, J.; Blomqvist, J.; Pickova, J.; Bonturi, N.; Sandgren, M.; Passoth, V. Lipid production from hemicellulose with Lipomyces starkeyi in a $\mathrm{pH}$ regulated fed-batch cultivation. Yeast 2016, 33, 451-462. [CrossRef]

238. Pereira, I.; Madeira, A.; Prista, C.; Loureiro-Dias, M.C.; Leandro, M.J. Characterization of new polyol/H+ symporters in Debaryomyces hansenii. PLoS ONE 2014, 9. [CrossRef]

239. Jönsson, L.J.; Alriksson, B.; Nilvebrant, N. Bioconversion of lignocellulose: Inhibitors and detoxification. Biotechnol. Biofuel. 2013, 6, 16. [CrossRef]

240. Park, Y.C.; Oh, E.J.; Jo, J.H.; Jin, Y.S.; Seo, J.H. Recent advances in biological production of sugar alcohols. Curr. Opin. Biotechnol. 2016, 37, 105-113. [CrossRef] [PubMed]

241. Chen, R.; Wang, Y.; Liao, Q.; Zhu, X.; Xu, T.F. Hydrolysates of lignocellulosic materials for biohydrogen production. BMB Rep. 2013, 46, 244-251. [CrossRef] [PubMed]

242. Huang, X.F.; Liu, J.N.; Lu, L.J.; Peng, K.M.; Yang, G.X.; Liu, J. Culture strategies for lipid production using acetic acid as sole carbon source by Rhodosporidium toruloides. Bioresour. Technol. 2016, 206, 141-149. [CrossRef] [PubMed]

243. Liu, Z.; Ho, S.H.; Hasunuma, T.; Chang, J.S.; Ren, N.Q.; Kondo, A. Recent advances in yeast cell-surface display technologies for waste biorefineries. Bioresour. Technol. 2016, 215, 324-333. [CrossRef] [PubMed]

244. Zhao, Y.; Wang, Y.; Zhu, J.Y.; Ragauskas, A.; Deng, Y. Enhanced enzymatic hydrolysis of spruce by alkaline pretreatment at low temperature. Biotechnol. Bioeng. 2008, 99, 1320-1328. [CrossRef]

245. Keshav, P.K.; Shaik, N.; Koti, S.; Linga, V.R. Bioconversion of alkali delignified cotton stalk using two-stage dilute acid hydrolysis and fermentation of detoxified hydrolysate into ethanol. Ind. Crop. Prod. 2016, 91, 323-331. [CrossRef]

246. Pival, S.L.; Birner-Gruenberger, R.; Krump, C.; Nidetzky, B. D-Xylulose kinase from Saccharomyces cerevisiae: Isolation and characterization of the highly unstable enzyme, recombinantly produced in Escherichia coli. Protein Expr. Purif. 2011, 79, 223-230. [CrossRef]

247. Hirasawa, H.; Shioya, K.; Mori, K.; Tashiro, K.; Aburatani, S.; Shida, Y.; Kuhara, S.; Ogasawara, W. Cellulase productivity of Trichoderma reesei mutants developed in Japan varies with varying $\mathrm{pH}$ conditions. J. Biosci. Bioeng. 2019, 128, 264-273. [CrossRef]

248. Claes, A.; Deparis, Q.; Foulquié-Moreno, M.R.; Thevelein, J.M. Simultaneous secretion of seven lignocellulolytic enzymes by an industrial second-generation yeast strain enables efficient ethanol production from multiple polymeric substrates. Metab. Eng. 2020, 59, 131-141. [CrossRef]

249. Won, K.Y.; Kim, Y.S.; Oh, K.K. Comparison of bioethanol production of simultaneous saccharification and fermentation and separation hydrolysis and fermentation from cellulose-rich barley straw. Korean J. Chem. Eng. 2012, 29, 1341-1346. [CrossRef] 
250. Gong, Z.; Shen, H.; Wang, Q.; Yang, X.; Xie, H.; Zhao, Z.K. Efficient conversion of biomass into lipids by using the simultaneous saccharification and enhanced lipid production process. Biotechnol. Biofuels 2013, 6, 36. [CrossRef] [PubMed]

251. Liu, W.; Wang, Y.; Yu, Z.; Bao, J. Simultaneous saccharification and microbial lipid fermentation of corn stover by oleaginous yeast Trichosporon cutaneum. Bioresour. Technol. 2012, 118, 13-18. [CrossRef]

252. Peng, X.; Chen, H. Single cell oil production in solid-state fermentation by Microsphaeropsis sp. from steam-exploded wheat straw mixed with wheat bran. Bioresour. Technol. 2008, 99, 3885-3889. [CrossRef] [PubMed]

253. Le, R.K.; Das, P.; Mahan, K.M.; Anderson, S.A.; Wells, T., Jr.; Yuan, J.S.; Ragauskas, A.J. Utilization of simultaneous saccharification and fermentation residues as feedstock for lipid accumulation in Rhodococcus opacus. AMB Express 2017, 7, 185. [CrossRef] [PubMed]

254. Tomás-Pejó, E.; Oliva, J.M.; González, A.; Ballesteros, I.; Ballesteros, M. Bioethanol production from wheat straw by the thermotolerant yeast Kluyveromyces marxianus CECT 10875 in a simultaneous saccharification and fermentation fed-batch process. Fuel 2009, 88, 2142-2147. [CrossRef]

255. Zhang, J.; Lynd, L.R. Ethanol production from paper sludge by simultaneous saccharification and co-fermentation using recombinant xylose-fermenting microorganisms. Biotechnol. Bioenergy 2010, 107, 235-244. [CrossRef] [PubMed]

256. Choudhary, J.; Singh, S.; Nain, L. Bioprospecting thermotolerant ethanologenic yeasts for simultaneous saccharification and fermentation from diverse environments. J. Biosci. Bioeng. 2017, 123, 342-346. [CrossRef]

257. Patel, A.; Matsakas, L.; Rova, U.; Christakopoulos, P. Heterotrophic cultivation of Auxenochlorella protothecoides using forest biomass as a feedstock for sustainable biodiesel production. Biotechnol. Biofuels 2018, 11, 169. [CrossRef]

258. Xiong, L.; Huang, C.; Yang, X.Y.; Lin, X.Q.; Chen, X.F.; Wang, C.; Wang, B.; Zeng, X.A.; Chen, X.D. Beneficial effect of corncob acid hydrolysate on the lipid production by oleaginous yeast Trichosporon dermatis. Prep. Biochem. Biotechnol. 2015, 45, 421-429. [CrossRef]

259. Chang, Y.H.; Chang, K.S.; Lee, C.F.; Hsu, C.L.; Huang, C.W.; Jang, H.D. Microbial lipid production by oleaginous yeast Cryptococcus sp. in the batch cultures using corncob hydrolysate as carbon source. Biomass Bioenergy 2015, 72, 95-103. [CrossRef]

260. Chen, X.F.; Huang, C.; Xiong, L.; Ma, L.L.; Chen, X.D. Microbial oil production from Corncob acid hydrolysate by Trichosporon cutaneum. Biotechnol. Lett. 2012, 34, 1025-1028. [CrossRef]

261. Gao, Q.; Cui, Z.; Zhang, J.; Bao, J. Lipid fermentation of corncob residues dhydrolysate by oleaginous yeast Trichosporon cutaneum. Bioresour. Technol. 2014, 152, 552-556. [CrossRef]

262. Gong, Z.; Zhou, W.; Shen, H.; Yang, Z.; Wang, G.; Zuo, Z.; Hou, Y.; Zhao, Z.K. Co-fermentation of acetate and sugars facilitating microbial lipid production on acetate-rich biomass hydrolysates. Bioresour. Technol. 2016, 207, 102-108. [CrossRef] [PubMed]

263. Huang, C.; Chen, X.F.; Xiong, L.; Chen, X.D.; Ma, L.L. Oil production by the yeast Trichosporon dermatis cultured in enzymatic hydrolysates of corncobs. Bioresour. Technol. 2012, 110, 711-714. [CrossRef]

264. Fei, Q.; O’Brien, M.; Nelson, R.; Chen, X.; Lowell, A.; Dowe, N. Enhanced lipid production by Rhodosporidium toruloides using different fed-batch feeding strategies with lignocellulosic hydrolysate as the sole carbon source. Biotechnol. Biofuels. 2016, 9, 130. [CrossRef] [PubMed]

265. Liu, Y.; Wang, Y.; Liu, H.; Zhang, J. Enhanced lipid production with undetoxified corncob hydrolysate by Rhodotorula glutinis using a high cell density culture strategy. Bioresour. Technol. 2015, 180, 32-39. [CrossRef]

266. Wells, T.; Wei, Z.; Ragauskas, A. Bioconversion of lignocellulosic pretreatment effluent via oleaginous Rhodococcus opacus DSM 1069. Biomass Bioenergy 2015, 72, 200-205. [CrossRef]

267. Xu, J.; Du, W.; Zhao, X.; Liu, D. Renewable microbial lipid production from oleaginous yeast: Some surfactants greatly improved lipid production of Rhodosporidium toruloides. World J. Microbiol. Biotechnol. 2016, 32, 107. [CrossRef] [PubMed]

268. Taoka, Y.; Nagano, N.; Okita, Y.; Izumida, H.; Sugimoto, S.; Hayashi, M. Effect of Tween 80 on the growth, lipid accumulation and fatty acid composition of Thraustochytrium aureum ATCC 34304. J. Biosci. Bioeng. 2011, 111, 420-424. [CrossRef]

269. Kumar, A.; Singh, L.K.; Ghosh, S. Bioconversion of lignocellulosic fraction of water-hyacinth (Eichhornia crassipes) hemicellulose acid hydrolysate to ethanol by Pichia stipitis. Bioresour. Technol. 2009, 100, 3293-3297. [CrossRef] 
270. Li, Y.; Qi, B.; Wan, Y. Separation of monosaccharides from pretreatment inhibitors by nanofiltration in lignocellulosic hydrolysate: Fouling mitigation by activated carbon adsorption. Biomass Bioenergy 2020, 136, 105527. [CrossRef]

271. Kundu, C.; Lee, J. Bioethanol production from detoxified hydrolysate and the characterization of oxalic acid pretreated eucalyptus (Eucalyptus globulus) biomass. Ind. Crop. Prod. 2016, 83, 322-328. [CrossRef]

272. Kim, Y.; Kreke, T.; Hendrickson, R.; Parenti, J.; Ladisch, M.R. Fractionation of cellulase and fermentation inhibitors from steam pretreated mixed hardwood. Bioresour. Technol. 2013, 135, 30-38. [CrossRef]

273. Singh, B.; Kumar, P.; Yadav, A.; Datta, S. Degradation of fermentation inhibitors from lignocellulosic hydrolysate liquor using immobilized bacterium, Bordetella sp. BTIITR. Chem. Eng. J. 2019, 361, 1152-1160. [CrossRef]

274. Tai, M.; Stephanopoulos, G. Engineering the push and pull of lipid biosynthesis in oleaginous yeast Yarrowia lipolytica for biofuel production. Metab. Eng. 2013, 15, 1-9. [CrossRef]

275. Quarterman, J.C.; Slininger, P.J.; Hector, R.E.; Dien, B.S. Engineering Candida phangngensis-an oleaginous yeast from the Yarrowia clade-for enhanced detoxification of lignocellulose-derived inhibitors and lipid overproduction. FEMS Yeast Res. 2018, 18, foy102. [CrossRef] [PubMed]

276. Quarterman, J.; Slininger, P.J.; Kurtzman, C.P.; Thompson, S.R.; Dien, B.S. A survey of yeast from the Yarrowia clade for lipid production in dilute acid pretreated lignocellulosic biomass hydrolysate. Appl. Microbiol. Biotechnol. 2017, 101, 3319-3334. [CrossRef] [PubMed]

277. Patel, A.; Arora, N.; Sartaj, K.; Pruthi, V.; Pruthi, P.A. Sustainable biodiesel production from oleaginous yeasts utilizing hydrolysates of various non-edible lignocellulosic biomasses. Renew. Sustain. Energy Rev. 2016, 62, 836-855. [CrossRef]

278. Shi, S.; Zhao, H. Metabolic engineering of oleaginous yeasts for production of fuels and chemicals. Front. Microbiol. 2017, 8, 2185. [CrossRef]

279. Chong, G.G.; Huang, X.J.; Di, J.H.; Xu, D.Z.; He, Y.C.; Pei, Y.N.; Tang, Y.; Ma, C.L. Biodegradation of alkali lignin by a newly isolated Rhodococcus pyridinivorans CCZU-B16. Bioproc. Biosyst. Eng. 2018, 41, 501-510. [CrossRef]

280. Kumar, L.R.; Yellapu, S.K.; Tyagi, R.D.; Zhang, X. A review on variation in crude glycerol composition, bio-valorization of crude and purified glycerol as carbon source for lipid production. Bioresour. Technol. 2019, 293, 122155. [CrossRef] [PubMed]

281. Parsons, S.; Allen, M.J.; Chuck, C.J. Coproducts of algae and yeast-derived single cell oils: A critical review of their role in improving biorefinery sustainability. Bioresour. Technol. 2020, 303, 122862. [CrossRef] [PubMed]

Publisher's Note: MDPI stays neutral with regard to jurisdictional claims in published maps and institutional affiliations.

(C) 2020 by the authors. Licensee MDPI, Basel, Switzerland. This article is an open access article distributed under the terms and conditions of the Creative Commons Attribution (CC BY) license (http://creativecommons.org/licenses/by/4.0/). 